\title{
Pola Komunikasi Keluarga Buruh Migran di Desan Pandan Wangi Kecamatan Jerowaru Kabupaten Lombok Timur
}

\author{
Prihartiningsih ${ }^{1}$, Agus Purbathin $\mathrm{Hadi}^{2}$, Diyah Indiyati ${ }^{3}$ \\ 1. Program Studi Ilmu Komunikasi, Universitas Mataram \\ 2. Program Studi Ilmu Komunikasi, Universitas Mataram \\ 3. Program Studi Ilmu Komunikasi, Universitas Mataram
}

\begin{abstract}
Migrant worker children left by one or both parents need to observe, the role of the missing father / mother in the family will certainly feel different compared to a complete family member of the family, children who live with fathers without mothers and children who live with you without father or child who lives with a grandmother without a mother and father we need to know. In this study consisted of three families of migrant workers left by both parents, abandoned by Father, and left by the mother in Pandan Wangi Village, Jerowaru District, East Lombok Regency.

The purpose of this study was to find out how the communication patterns of migrant workers' families and children's communication behavior in the families of migrant workers in Pandan Wangi Village, Jerowaru District, East Lombok Regency. The research was conducted using a research method through a descriptive approach with qualitative data. The results of the research showed in the families of migrant workers left by one of their parents mother / father applying a family communication pattern that leads to unbalanced split patterns which are unequal separate relationships, where one person in the wife / husband's family dominates.
\end{abstract}

Abstrak

Anak buruh migran yang ditingggalkan oleh salah satu dan atau kedua orang tuanya perlu kita amati, peran Ayah/Ibu yang hilang dalam keluarga tentu akan merasa berbeda dibandingkan dengan keluarga yang lengkap anggota keluarganya, anak yang tinggal dengan ayah tanpa ibu dan anak yang tinggal dengan Ibu tanpa Ayah ataupun anak yang tinggal dengan nenek tanpa ibu dan ayah perlu kita ketahui. Dalam penelitian ini terdiri dari tiga keluarga buruh migran yang ditinggalkan oleh kedua orangtua, ditinggalkan oleh Ayah, dan di tingalkan oleh ibu di Desa Pandan Wangi, Kecamatan Jerowaru, Kabupaten Lombok Timur.

Tujuan dari penelitian ini adalah untuk mengetahui bagaimana pola komunikasi keluarga buruh migran dan perilaku komunikasi anak dalam keluarga buruh migran di Desa Pandan Wangi, Kecamatan Jerowaru, Kabupaten Lombok Timur. Penelitian dilakukan dengan menggunakan metode penelitian melalui pendekatan deskriptif dengan data kualitatif.Hasilpenelitianmenunjukkandalam keluarga buruh migran yang ditinggalkan oleh salah satu orangtuanya ibu/ ayah menerapkan Pola komunikasi keluarga yang mengarah kepada komunikasi tak seimbang terpisah (Unbalanced Split Pattern) yaituhubungan terpisah yang tidak seimbang, di mana satu orang dalam keluarga si istri/suami mendominasi.

Kata kunci: Polakomunikasikeluarga, Buruh migran, Lombok Timur. 


\section{Pendahuluan}

Lombok Timur merupakan salah satu daerah yang menjadi basis buruh migran, pada Tahun 2015 terdapat 13.594 tenaga kerja yang diberangkatkan. Berdasarkan data tenaga kerja Indonesia yang diberangkatkan negara Malaysia merupakan negara tujuan yang paling diminati dengan jumlah 12.883. Tabel 1.1 menunjukkan banyaknya Tenaga Kerja Indonesia (TKI) yang diberangkatkan menurut negara tujuan.

Tabel 1.1 Tenaga Kerja Indonesia (TKI) yang diberangatkan menurut negara tujuan di Kabupaten Lombok Timur.

\begin{tabular}{cccc}
\hline Negara Tujuan & Laki-laki & Perempuan & Jumlah \\
\hline Malaysia & 12.527 & 356 & 12.883 \\
Arab Saudi & 55 & 72 & 127 \\
Negara Arab lainnya & & 141 & 141 \\
Singapura & & 88 & 88 \\
Brunei Darussalam & 129 & 78 & 207 \\
Jepang & - & - & - \\
Korea & - & - & - \\
Taiwan & 13 & 92 & 105 \\
Negara lainnya & - & 43 & 43 \\
\hline Total & $\mathbf{1 2 . 7 2 4}$ & $\mathbf{8 7 0}$ & $\mathbf{1 3 . 5 9 4}$ \\
\hline
\end{tabular}

Sumber Data:Dinas sosial, Ketenagakerjaan dan Transmigrasi, Kabupaten Lombok Timur Menurut hasil wawancara dengan Zahidun selaku aktivisDesa Pandan Wangi, Keacamatan Jerowaru, Kabupaten Lombok Timur juga merupakan desa yang menjadi basis buruh migran yang dominan. Pada Tahun 2017 menurut data dari Desa Pandan Wangi, Kecamatan Jerowaru, Kabupaten Lombok Timur, sebanyak 401 data anak buruh yang terbagi menjadi dua kategori yaitu kategori terlantar dan ABM (Anak Buruh Migran), 119 data anak buruh migran dikategorikan terlantar karena darikondisi anak yang memang ditelantarkan dan tidak terurus, tidak mendapatkan perhatian, kasih sayang dan juga kontrol, 212 data anak dikategorikan sebagai ABM (Anak Buruh Migran) karena memang mendapatkan pengasuhan yang lebih baik dan sedangkan sebanyak 70 data anak buruh migran belum memiliki keterangan dari kepala dusun setempat (wawancara tanggal, 03 April 2018).

Hasil wawancara pada hari Sabtu tanggal 11 November 2017 dengan Staf Desa Pandan Wangi yaitu Bapak Syaraffudin, 42 Tahun, Desa Pandan Wangi merupakan Desa yang berpotensi di bidang pertanian sehingga sebagian besar masyarakat Desa Pandan Wangi berprofesi sebagai Petani padi dan tembakau, persoalan muncul ketika petani gagal panen maka salah satu jalan 
keluar untuk menutupi kerugian dengan cara pergi meninggalkan keluarga menjadi Tenaga Kerja di Luar Negeri demi memenuhi kebutuhan hidup kedepannya, meninggalkan keluarga adalah salah satu pilihan yang harus dijalankan bertahun-tahun oleh seorang buruh migran, lebih-lebih meninggalkan anak yang pada masanya membutuhkan kasih sayang yang lengkap dari seorang Ibu dan Ayah (Wawancara tanggal 11 November 2017).

Perhatian dan kasih sayang adalah kebutuhan mendasar bagi anak, lingkungan rumah selain berfungsi sebagai tempat berlindung juga berfungsi sebagai tempat memenuhi kebutuhan mental anak misalnya, kebutuhan bergaul, kebutuhan rasa aman dan sebagai wahana untuk mengasuh anak hingga dewasa, dengan kata lain lingkungan keluarga memiliki andil besar dalam perkembangan anak. Kedekatan hubungan antara orangtua dan anak tentu akan berpengaruh secara emosional, anak merasa dibutuhkan dan berharga dalam keluarga apabila orangtuanya memberi perhatiannya kepada anak. Anak akan menganggap bahwa keluarga merupakan bagian dari dirinya yang dibutuhkan dalam segala hal. Sebaliknya, hubungan yang kurang harmonis antara orangtua dan anak akan berdampak buruk terhadapperkembangan anak, tidak jarang anak-anak terjerumus ke hal-hal yang negatif dengan alasan orangtua kurang memberikan perhatian kepada anak.

Keluarga menurut Bussard dalam Dodiet (2012) merupakan lingkungan sosial yang mempunyai hubungan yang sangat erat dengan seseorang. Dalam keluarga itulah seseorang dibesarkan, bertempat tinggal, berinteraksi antara satu dengan yang lainnya, terbentuknya nilainilai dan kebiasaan-kebiasaan yang berfungsi sebagai segenap budaya dari luar dan mengakomodasi hubungan anak dengan lingkungannya. Selain itu keluarga juga memiliki perananan dalam mengajarkan, membimbing dalam menentukan perilaku dan membentuk cara pandang anak terhadap nilai-nilai yang berlaku di dalam masyarakat, keluarga layaknya memberikan peranan nilai yang dibutuhkan anak melalui suatu pola komunikasi yang sesuai sehingga komunikasi berjalan dengan baik dan tercipta hubungan yang harmonis serta pesan dan nilai-nilai yang disampaikan diterima dengan baik.

Menurut Suciati (2015) komunikasi dalam keluarga dapat diartikan sebagai kesiapan membicarakan dengan terbuka setiap hal dalam keluarga baik yang menyenangkan maupun yang tidak menyenangkan dan juga siap menyelesaikan masalah dalam keluarga dengan pembicaraan yang dijalani dengan kesabaran dan kejujuran serta dengan keterbukaan. Salah satu bentuk komunikasi dalam keluarga adalah komunikasi orangtua dengan anak. Komunikasi yang terjalin 
antara orangtua dan anak terjalin dalam satu ikatan keluarga dimana orangtua bertanggung jawab dalam mendidik anak. Hubungan yang terjalin antara orangtua dan anak disini bersifat dua arah, disertai dengan pemahaman bersama terhadap sesuatu hal dimana antara orangtua dan anak berhak menyampaikan pendapat pikiran dan informasi atau nasihat.

Arah komunikasi yang tepat akan membuat keberlangsungan komunikasi berjalan lancar dan tepat sasaran. Anak-anak zaman sekarang telah memiliki ciri tersendiri saat menetapkan pendapat maupun keinginannya. Hal inilah yang harus dipahami orangtua agar bisa menentukan sikap secara bijak. Perlunya komunikasi dua arah, dimana anak-anak diberikan ruang dan waktu untuk menjadi dirinya sendiri adalah hal yang sangat bijak untuk menghindari kekecewaan sang anak baik terhadap dirinya maupun terhadap lingkungannya. Selain pendekatan orangtua juga memahami sifat dan karakter anak yang memulai berkembang membentuk kepribadian.

Agar komunikasi orangtua dapat diterima oleh anak maka perlu meluangkan waktu, dengan melakukan pendekatan persuasif walaupun sekedar mendengarkan cerita dan pendapat sang anak tentang apapun. Sesibuk apapun orangtua tetap berkewajiban menjaga dan mendampingi tumbuh kembangnya jiwa dan jasmani anak. Sudah saatnya orangtua lebih memperhatikan, merangkul sang anak dan bersama-sama duduk dalam membicarakan permasalahan yang ada. Ketika orangtua tetap pada keegoisannya mustahil orangtua dan anak akan akrab dan menyatu apalagi menyelesaikan masalah yang semakin kompleks.

Komunikasi yang lancar dan sehat dalam anggota keluarga dan individu-individu lainnyaterdapat keterikatan, saling berhubungan dan saling memerlukan. Oleh karena ituadanya komunikasi yang lancar dan harmonis dalam keluarga sangat didambakan oleh setiap anggota keluarga agar berlangsung dengan terus dan intensif, dengan adanya komunikasi yang baik dalam sebuah keluarga tidak terlepas dari peran kedua orangtua karena keduanya memberikan bimbingan dan contoh yang baik berupa suri tauladan kepada anak-anaknya agar mereka hidup selamat dan sejahtera (Hilmi,2008).

Dalam konteks ini peran orangtua Ayah dan Ibu sangat membantu anak untuk menggapai impiannya dengan penanaman komunikasi yang tepat, namun dilihat dari sisi anak buruh migran yang ditingggalkan oleh salah satu dan atau kedua orang tuanya juga perlu kita amati, peran Ayah/Ibu yang hilang dalam keluarga tentu akan merasa berbeda dibandingkan dengan keluarga yang lengkap anggota keluarganya, anak yang tinggal dengan ayah tanpa ibu 
dan anak yang tinggal dengan ibu tanpa ayah ataupun anak yang tinggal dengan nenek tanpa ibu dan ayah perlu diperhatikan.

Berdasarkan uraian diatas, maka penulis tertarik untuk meneliti dan membahasnya yang dituangkan dalam skripsi yang berjudul "Pola komunikasi keluarga buruh migran di Desa Pandan Wangi, Kecamatan Jerowaru, Kabupaten Lombok Timur”.

Adapun perumusan masalah dalam penelitian ini adalah sebagai berikut:

1. Bagaimana pola komunikasi keluarga buruh migran di Desa Pandan Wangi, Kecamatan Jerowaru, Kabupaten Lombok Timur?

2. Bagaimana perilaku komunikasi anak dalamkeluarga buruh migran di Desa Pandan Wangi, Kecamatan Jerowaru, Kabupaten Lombok Timur?

Berdasarkan pada perumusan masalah, maka tujuan dari penelitian ini adalah sebagai berikut:

1. Untuk mengetahui pola komunikasi keluarga buruh migran di Desa Pandan Wangi, Kecamatan Jerowaru, Kabupaten Lombok Timur Untuk mengetahui perilaku komunikasi anak dalamkeluarga buruh migran

\section{Tinjauan Pustaka}

Kehidupan manusia tidak bisa lepas dari sebuah komunikasi, baik yang bersifat verbal maupun non verbal. Komunikasi itu sendiri berlangsung dalam berbagai konteks, mulai dari komunikasi interpersonal, komunikasi kelompok, komunikasi organisasi sampai dengan komunikasi massa. Masing-masing konteks memiliki karakteristik unik yang semuanya menghendaki adanya efektivitas dalam prosesnya.

Komunikasi antarpribadi (interpersonal communication) adalah komunikasi yang berlangsung dalam diri kita, meliputi kegiatan dalam diri sendiri dan kegiatan-kegiatan yang mengamati dan memberikan makna (intelektual dan emosional) kepada lingkungan kita Effendy (1993).

Richard dalam Budyatna (2011) menyebutkan ada 8 karakteristik komunikasi interpersonal :

1. Melibatkan paling setidaknya dua orang

2. Adanya umpan balik

3. Tidak harus tatap muka

4. Tidak harus bertujuan 
5. Menghasilkan beberapa pengaruh/efek

6. Tidak harus menggunakan kata-kata

7. Dipengaruhi oleh konteks

8. Dipengaruhi oleh kegaduhan

Komunikasi yang baik dan tepat sasaran dipengaruhi beberapa faktor diantaranya (Suciati, 2015) :

a. Perkembangan setiap pribadi dalam memandang masalah atau topik yang disampaikan.

b. Media komunikasi yang memudahkan untuk berhubungan

c. Peranan anggota keluarga dalam menanggapi opini atau ide-ide anggota kelurganya

d. Tema atau topik setiap permasalahan yang dihadapi

e. Faktor eksternal yang sangat mempengaruhi terciptanya kondisi yang kondusif untuk menciptakan komuniksi yang terarah.

\section{Model Komunikasi Interpersonal}

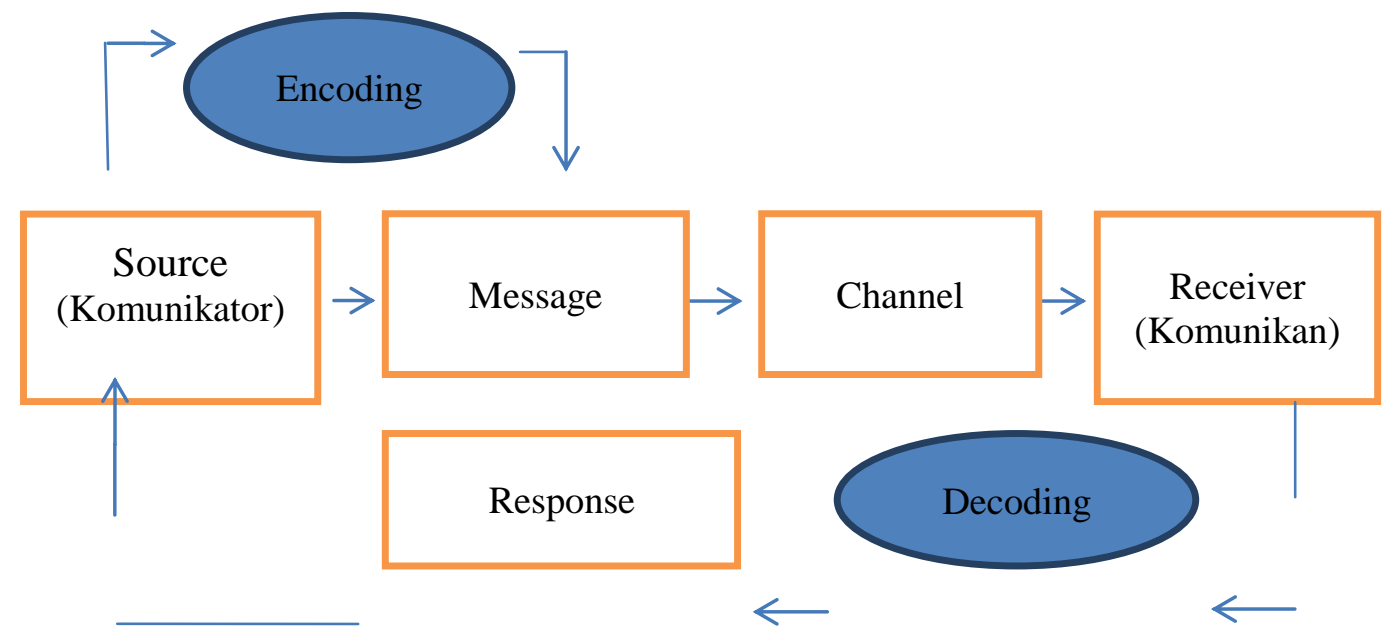

Proses Komunikasi Interpersonal (Model Komunikasi Berlo, 1996)

Proses komunikasi antarpribadi atau komunikasi interpersonal arus komunikasi yang terjadi adalah sirkuler atau berputar, artinya setiap individu mempunyai kesempatan yang yang sama untuk menjadi komunikator dan komunikan karena dalam komunikasi antarpribadi.

Konteks yang melingkupi komunikasi interpersonal meliputi konteks jasmaniah, sosial historis, psikologis, dan kultural. Ketika Budyatna menyoroti sisi psikologis dalam 
sebuah hubungan interpersonal, De Vito (2004) lebih menyoroti karakteristik komunikasi interpersonal berdasarkan sisi keintiman. Sebuah komunikasi interpersonal adalah sebuah bentuk komunikasi yang terdiri dari dua orang dengan hubungan yang mantap, hubungan personal yang saling menguntungkan serta adanya kesadaran dari masing-masing partisipan untuk berfikir positif tentang hubungan mereka, hal ini terwujud antara anak dan orang tuanya, dua saudara murid dan guru, sepasang kekasih, dua sahabat, dan sebagainya.

\section{Faktor-Faktor yang Mempengaruhi Efektivitas Komunikasi Interpersonal}

Menurut De Vito (2004), faktor- faktor yang mempengaruhi efektifitas komunikasi interpersonal yaitu :

\section{a) Keterbukaan (openness)}

Keterbukaan merupakan kemauan menanggapi dengan senang hati informasi yang diterima dalam menghadapi hubungan antar pribadi. Kualitas keterbukaan mengacu pada tiga aspek dari komunikasi interpersonal. Mampu memahai motivasi dan pengalaman orang lain, perasaan dan sikap mereka, serta harapan dan keinginan mereka untuk masa mendatang sehingga dapat mengkomunikasikan empati, baik secara verbal maupun non verbal.

b) Empati (emphaty)

Empati adalah kemampuan seseorang untuk mengetahui apa yang sedang dialami orang lain pada suatu saat tertentu, dari sudut pandang orang lain itu, melalui kacamata orang lain itu. Berbeda dengan simpati yang artinya adalah merasakan bagi orang lain. Orang yang berempati mempengaruhi. Proses saling mempengaruhi ini merupakan permulaan dari ikatan psikologis antara manusia yang memiliki suatu pribadi.

c) Dukungan (supportiveness)

Dukungan adalah situasi yang terbuka untuk mendukung komunikasi berlangsung efektif. Hubungan interpersonal yang efektif adalah hubungan dimana terdapat sifat mendukung dengan bersikap deskriptif bukan evaluasi, spontan dan bukan strategik.

d) Rasa Positif (possitiveness)

Seseorang harus memiliki perasaan positif terhadap dirinya, mendorong orang lain lebih aktif berpartisipasi, dan menciptakan situasi komunikasi kondusif untuk interaksi yang efektif.

e) Kesetaraan (equality) 
Kesetaraan adalah komunikasi antarpribadi yang lebih efektif bila suasananya secara diam-diam bahwa kedua belah pihak menghargai, berguna, dan mempunyai sesuatu yang penting untuk disumbangkan.

\section{Komunikasi Interpersonal dalam Keluarga}

Komunikasi interpersonal merupakan suatu hal yang sangat paling penting,dimana komunikasi sebagai alat atau media sebagai penghubung dalam hubungan antar sesama anggota keluarga. Komunikasi antar pribadi yang paling sederhana dapat kita amati di dalam keluarga. Suatu keluarga terdiri dari pribadi-pribadi yakni ayah, ibu dan anak-anak. Peranan dalam menciptakan anggota keluarga sangat kuat sekali . masing-masing diharapkan mengetahui peranan di dalam keluarga. Keluarga merupakan suatu sistem suatu kesatuan yang dibentuk oleh bagian-bagian yang saling berhubungan dan berinteraksi antara satu dengan yang lainnnya. Agar terjadi komunikasi yang seimbang dibutuhkan pengertian oleh orangtua dan anak mengenai suatu tujuan yang diharapkan. Keluarga yang seimbang adalah keluarga yang ditandai oleh keharmonisan hubungan antara ayah, ibu dan anak, serta antara ibu dan anak.

Dalam keluarga, komunikasi juga menjadi hal yang penting yang dapat menjadi penentu dalam keberhasilan berkelurga. Menurut Balson dalam Abriyoso (2012) komunikasi yang efektif apabila orang yang mengungkapkan keprihatinan dan masalah bahwa pendengarnya memahami perasaan yang sedang disampaikan. Komunikasi yang buruk antara ayah, ibu dan anak seringkali menciptakan konflik yang tidak berkesudahan, bentuk konflik yang ditimbulkan juga sangat beragam dan solusi semua konflik adalah komunikasi yang baik, penuh pengertian dan saling menghargai dan menyayangi serta ingin saling membahagiakan.

\section{Pola Komunikasi}

Rogers dan Kincaid dalam Wiryanto (2004) menyatakan bahwa komunikasi adalah suatu proses dimana dua orang atau lebih membentuk atau melakukan pertukaran informasi antara satu sama lain, yang pada gilirannya terjadi saling pengertian yang mendalam. Istilah pola komunikasi biasa disebut juga sebagai model tetapi maksudnya sama, yaitu sistem yang terdiri atas berbagai komponen yang berhubungan satu sama yang lainnya untuk mencapai tujuan pendidikan keadaan masyarakat. 
Pola komunikasi merupakan suatu sistem penyampaian pesan melalui lambang tertentu, mengandung arti, dan pengoperan perangsang untuk mengubah tingkah laku individu lain. Pola komunikasi dapat dipahami sebagai pola hubungan antara dua orang atau lebih dalam pengiriman dan penerimaan pesan dengan cara yang tepat sehingga pesan yang dimaksud dapat dipahami (Djarmah,2004).

Menurut Djarmah (2004) pola komunikasi terdiri atas berbagai macam :

\section{Pola komunikasi satu arah}

Proses penyampaian pesan dari komunikator kepada komunikan baik menggunakan media atau tanpa menggunakan media, tanpa ada umpan balik dari komunikan, dalam hal ini komunikan bertindak sebagai pendengar saja.

2. Pola komunikasi dua arah atau timbal balik (two way traffic communicaton).

Komunikator dan komunikan menjadi saling tukar fungsi dalam menjalani fungsi mereka, komunikator dalam tahap pertama menjadi komunikan dan pada tahap kedua berikutnya saling bergantian fungsi. Namun hakekatnya yang memulai percakapan adalah komunikator utama, komunikator utama mempunyai tujuan tertentumelalui proses komunikasi tersebut, prosesnya dialogis, serta umpan balik terjadi secara langsung.

\section{Pola komunikasi multiarah}

Proses komunikasi terjadi dalam satu kelompok yang lebih banyak dimana komunikator akan bertukar pikiran secara dialogis.

Komunikasi adalah proses penyampaian informasi (pesan, ide, gagasan) dari satu pihak kepada pihak lain. Pada umumnya komunikasi digunakan secara lisan atau verbal yang dapat dimenegrti kedua belah pihak, apabila tidak ada komunikasi verbal yang dapat mengerti olehnya, komunikasi masih dapat digunakakan dengan menggunakan non verbal (gerak-gerik badan, tersenyum). Komunikasi adalah proses penyampaian pesan oleh seseorang kepada orang lain untuk memberitahu, mengubah sikap, pendapat, atau perilaku, baik secara lisan(langsung) ataupun tidak langsung (Effendy,2003).

Keluarga merupakan konsep yang bersifat multidimensi. Berdasarkan penelitiannya Murdock menyatakan bahwa keluarga merupakan kelompok sosial yang bersifat universal. Para anggota keluarga inti bukan hanya membentuk kelompok sosial, melainkan juga menjalankan empat fungsi universal dari keluarga, yaitu seksual, reproduksi, pendidikan dan ekonomi, Struktur keluarga (Sri L, 2012). 
Dari segi keberadaan anggota keluarga maka keluarga dapat dibedakan menjadi dua, yaitu keluarga inti (nuclear family) dan keluarga besar (extended family). Keluarga inti adalah keluarga yang didalamnya hanya terdapat tiga posisi sosial, yaitu suami-ayah, istri-ibu, sedangkan keluarga besar yaitu anggota inti di tambah anggota lain yang masih mempunyai hubungan darah, seperti kakek, nenek, paman dan bibik. Struktur keluarga adalah serangkaian tuntunan fungsional tidak terlihat yang mengorganisasi cara-cara anggota keluarga dalam berinteraksi. Sebuah keluarga merupakan sebuah sistem yang beroperasi melalui pola transaksi. Pengulangan transaksi membentuk pola bagaimana, kapan, dan dengan siapa berelasi dan pola tersebut mendukung sistem (Setyawan, 2012).

Komunikasi merupakan aspek yang paling penting, karena berkaitan dengan hampir semua aspek yang paling dalam hubungan. Hasil dari semua diskusi dan pengambilan keputusan di keluarga yang mencakup keuangan, anak, karier, agama bahkan dalam pengungkapan perasaan, hasrat kebutuhan akan tergantung pada gaya/pola dan keterampilan berkomunikasi. Keterampilan dalam berkomunikasi dapat mewujud dalam kecermatan memilih kata yang digunakan dalam menyampaikan gagasan pada pasangan (Sri L, 2012).

Pola komunikasi keluarga merupakan salah satu faktor yang penting, karena keluarga merupakan lembaga sosial pertama yang dikenal anak selama proses sosialisasinya. Menurut Devito dalam Saputra (1986) ada empat pola komunikasi dalam keluarga secara umum yaitu:

\section{Pola komunikasi persamaan (Equality Pattren)}

Tiap individu berbagai hak sama-sama dalam kesempatan berkomunikasi. Peran tiap orang dijalankan secara merata. Komunikasi berjalan dengan jujur, terbuka, langsung, dan bebas dari pembagian kekuasaan. Semua orang memiliki hak yang samadalam proses pengambilan keputusan, keluarga mendapatkan kepuasan tertinggi bila ada kesetaraan.

2. Pola komunikasi seimbang terpisah (Balance Split Pattern)

Kesetaraan hubungan tetap terjaga namun dalam pola ini tiap orang memiliki daerah kekuasaan yang berbeda dari yang lainnya. Tiap orang dilihat sebagai ahli dalam bidang yang berbeda. Sebagai contoh, dalam keluarga normal/tradisional, suami dipercaya dalam urusan bisnis atau politik. Istri dipercaya untuk urusan perawatan anak dan memasak. Namun pembagian peran berdasarkan jenis kelamin ini masihbersifat fleksibel. Konflik yang terjadi dalam keluarga tidak dipandang sebagai ancaman karena tiap individu memiliki area masing-masing dalam keahlian sendiri-sendiri. 
3. Pola komunikasi tak seimbang terpisah (Unbalanced Split Pattern)

Satu orang mendominasi, satu orang dianggap sebagai ahli lebih dari yang lainnya. Satu orang inilah yang memegang kontrol, seseorang ini biasanya memiliki kecerdasan intelektual lebih tinggi, bijaksana, atau berpenghasilan lebih tinggi. Anggota keluarga yang lain berkompensasi dengan cara tunduk pada seseorang tersebut, membiarkan orang yang mendominasi memenangkan argumen dan pengambilan keputusan sendiri.

4. Pola komunikasi monopoli (Monopoly Pattern)

Satu orang dipandang sebagai pemegang kekuasaan. Satu orang ini lebih bersifat memberi perintah daripada berkomunikasi. Ia mengambil hak penuh dalam mengambil keputusan sehingga jarang atau tidak pernah bertanya atau meminta pendapat dari orang lain. Pemegang kuasa memerintahkan kepada orang lainapa yang boleh dan tidak boleh dilakukan. Maka anggota keluarga yang lainnya meminta izin, meminta pendapat, dan membuat keputusan berdasarkan keputusan dari orang tersebut.

Pola komunikasi ini menggambarkan pembagian peran dan kedudukan masingmasing individu dalam sebuah keluarga. Komunikasi keluarga turut berperan dalam penerimaan pesan dan umpan balik yang terjadi antar anggota keluarga, sebagai contoh dalam pola komunikasi monopoli, hanya satu orang yang mengambil keputusan dalam keluarga hal ini menyebabkan anggota keluarga yang lain tidak berhak menyuarakan pendapat atau turut berperan dalam pengambilan keputusan, yang mengakibatkan komunikasi keluarga cenderung menjadi komunikasi satu arah saja. Demikian juga dalam penanaman dan pengembangan nilai, nilai- nilai yang ditanamkan oleh pemegang kekuasaan mutlak diikuti oleh anggota keluarga yang lainnya karena komunikasi yang berlangsung hanya bersifat instruksi atau arahan.

\section{Definisi Keluarga}

Keluarga merupakan konsep yang bersifat multidimensi. Berdasarkan penelitiannya tersebut Murdock menyatakan bahwa keluarga merupakan kelompok sosial yang bersifat universal. Para anggota keluarga inti bukan hanya membentuk kelompok sosial, melainkan juga menjalankan empat fungsi universal dari keluarga, yaitu seksual, reproduksi, pendidikan dan ekonomi.

Dari segi keberadaan anggota keluarga maka keluarga dapat dibedakan menjadi dua, yaitu keluarga inti (nuclear family) dan keluarga besar (extended family). Keluarga inti 
adalah keluarga yang didalamnya hanya terdapat tiga posisi sosial, yaitu suami-ayah,istriibu, sedangkan keluarga besar yaitu anggota inti ditambah anggota lain yang masih mempunyai hubungan darah, seperti kakek, nenek, paman dan bibi. Struktur keluarga adalah serangkaian tuntunan fungsional tidak terlihat yang mengorganisasi cara-cara anggota keluarga dalam berinteraksi. Sebuah keluarga merupakan sebuah sistem yang beroperasi melalui pola transaksi. Pengulangan transaksi membentuk pola bagaimana, kapan, dan dengan siapa berelasi dan pola tersebut mendukung sistem (Setyawan D.A, 2012)

Komunikasi merupakan aspek yang paling penting, karena berkaitan dengan hampir semua aspek yang paling dalam hubungan. Hasil dari semua diskusi dan pengambilan keputusan di keluarga, yang mencakup keuangan, anak, karier,agama bahkan dalam pengungkapan perasaan, hasrat kebutuhan akan tergantung pada gaya, pola dan keterampilan berkomunikasi. Keterampilan dalam berkomunikasi dapat mewujud dalam kecermatan memilih kata yang digunakan dalam menyampaikan gagasan pada pasangan (SriLestari, 2012).

\section{Perkembangan Perilaku}

Perkembangan yang dimaksud adalah suatu proses tertentu secara terus menerus dan proses yang menuju kedepan dan tidak dapat begitu saja dapat diulang kembali, atau secara umum dapat diartikan sebagai serangkaian perubahan dalam sususan yang berlangsung secara teratur, progresif, jalin-menjalin, dan terarah kepada kematangan dan kedewasaan (Sabri,MA,1996).

Faktor -Faktor yang Mempengaruhi Perilaku Anak

Pembentukan perilaku akan terjadi dengan sendirinya meskipun perilaku tersebut dibawa dari lahir tetapi perilaku dalam diri seseorang dapat terbentuk melalui pengalaman-pengalaman dan interaksi manusia dengan objek-objek tertentu secara terulang-ulang dan perilaku pada setiap diri seorang pasti ada yang mempengaruhi baik yang berasal dari dalam maupun dari luar dirinya sendiri.

Adapun faktor-faktor yang mempengaruhi pembentukan perilaku seseorang menurut Sondang (1985) adalah sebagai berikut :

1. Faktor genetik adalah faktor keturunan atau unsur bawaan ialah proses yang dibawa setiap individu ketika ia lahir yang merupakan warisan dari orangtuanya, berupa ciri-ciri atau sifat secara fisik, serta kemampuan berupa bakat, sifat pemarah atau penyabar dan sebagainya. 
Semua itu merupakan potensi dasar atau faktor bawaan yang akan mempengaruhi proses tumbuh kembangnya anak.

2. Faktor lingkungan adalah situasi atau kondisi seseorang didalam rumah dan lingkungan yang lebih luas, terutama lingkungan sekolah atau masyarakat yang dilihat dan dihadapi seharihari dimana semuanya tempat bernaung, sebagai tempat memecahkan segala persoalan sekaligus sebagai tempat untuk menemukan panutan yang akan dijadikan teladan untuk menentukan berperilaku.

Sedangkan menurut Kurniawan(1992) mengatakan bahwa pada dasarnya setiap individu berperilaku dimotivasi oleh dua kebutuhan yang saling berkaitan yaitu: kebutuhan yang diterima oleh kelompok atau orang lain disekitarnya dan kebutuhan menghindari dari penolakan atau orang lain disekitarnya.

1. Faktor pembawaan dan kelahiran yang cenderung memberi corak dan perilaku tertentu pada yang bersangkutan.

2. Faktor keluarga dimana lingkungan keluarga banyak berperan dalam menghiasi perilaku anak.

3. Faktor pengalaman dalam masyarakat sekitar, karena watak manusia sangat dipengaruhi oleh kecendrungan-kecendrungan dan norma-norma sosial, kebudayaan, konsep-konsep, gaya hidup, bahasa dan keyakinan yang dipeluk oleh masyarakat.

\section{Dampak Perilaku Anak}

Berdasarkan penelitian terdahulu yang dilakukan oleh Permatasari, B (2015) menyatakan bahawa anak yang ditinggalkan orangtuanya merantau membawa dampak kepada psikologi anak menunjukkan sikap yang pendiam, minder, dan mandiri, dan juga memiliki tekad yang kuat dan tegas namun mempunyai sifat tertutup. Pergaulan anak di sekolah menunjukkan sikap anak yang susah bergaul dan kurang akrab dengan teman satu kelas, dan juga kurang percaya diri dengan teman-temannya sehingga muncul sikap kesenjangan dengan teman dan juga mempunyai hubungan yang baik dalam berkomunikasi dengan teman-temannya dan anak juga menunjukkan sikap yang kurang baik, tidak sopan dan mengarah pada kenakalan. Anak memiliki prestasi yang kurang baik, anak pernah tidak naik kelas dan nilai rapor juga kurang memuaskan itu disebabkan karena kurangnya perhatian dari keluarga. 


\section{Kerangka berfikir /konsep}

Dalam hidup berkeluarga dan bermasyarakat seseorang bisa memperoleh kemudahan-kemudahan dari hidupnya karena banyak memiliki anggota keluarga yang lengkap. Melalui komunikasi dalam keluarga jika dapat dibina hubungan yang baik akan dapat menghindari dan mengatasi konflik-konflik diantara anggota keluarga, lingkungan kelurga memiliki peran penting dalam perkembangan psikologi anak. Ada empat pola komunikasi dalam keluarga yang umum pada keluarga inti komunikasi keluarga yang terdiri atas pola persamaan (Equality Pattern), pola seimbang terpisah (Balance Split Pattern), pola tak seimbang terpisah (Unbalance Split Pattern) pola monopoli (Monopoly Pattern).

Pola komunikasi ini menggambarkan pembagian peran dan kedudukan masing masing individu dalam sebuah keluarga. Komunikasi keluarga turut berperan dalam penerimaan pesan dan umpan balik yang terjadi antar anggota keluarga.Dari pembagian peran dan kedudukan dalam keluarga tentu akan mempengaruhi gaya komunikasi interpersonal sang anak yaitu antara anak dan orangtua dan antara anggota keluarga yang lain bahkan dengan teman sebaya dan lingkungan sekitar, dan hal ini akan mengarah kepada bagaimana keterbukaan anak kepada orangtua, bagaimana mental anak dalam menjalankan kehidupan sehari-harinya tentu akan mempengaruhi pola perkembangan anak dalam bersikap dan mengambil keputusan, jika anak tidak bisa menyalurkan pendapat dengan baik maka akan memberikan dampak negatif kepada kehidupan pribadi sang anak.

Tujuan dari penelitian ini agar dapat menjadi pembelajaran bagi orangtua bagaimana orangtua dalam bersikap dalam menyampaikan pendapat, mengambil tindakan atau arahan kepada anak dalam masanya yang belum memiliki tujuan dan pandangan. Penelitian ini dilaksanakan untuk mengetahui pola komunikasi keluarga buruh migran di Desa Pandan Wangi, Kecamatan Jerowaru, Kabupaten Lombok Timur. Untuk lebih jelasnya dapat dilihat pada bagan berfikir 2.2 sebagai berikut 


\section{Kerangka Berfikir}

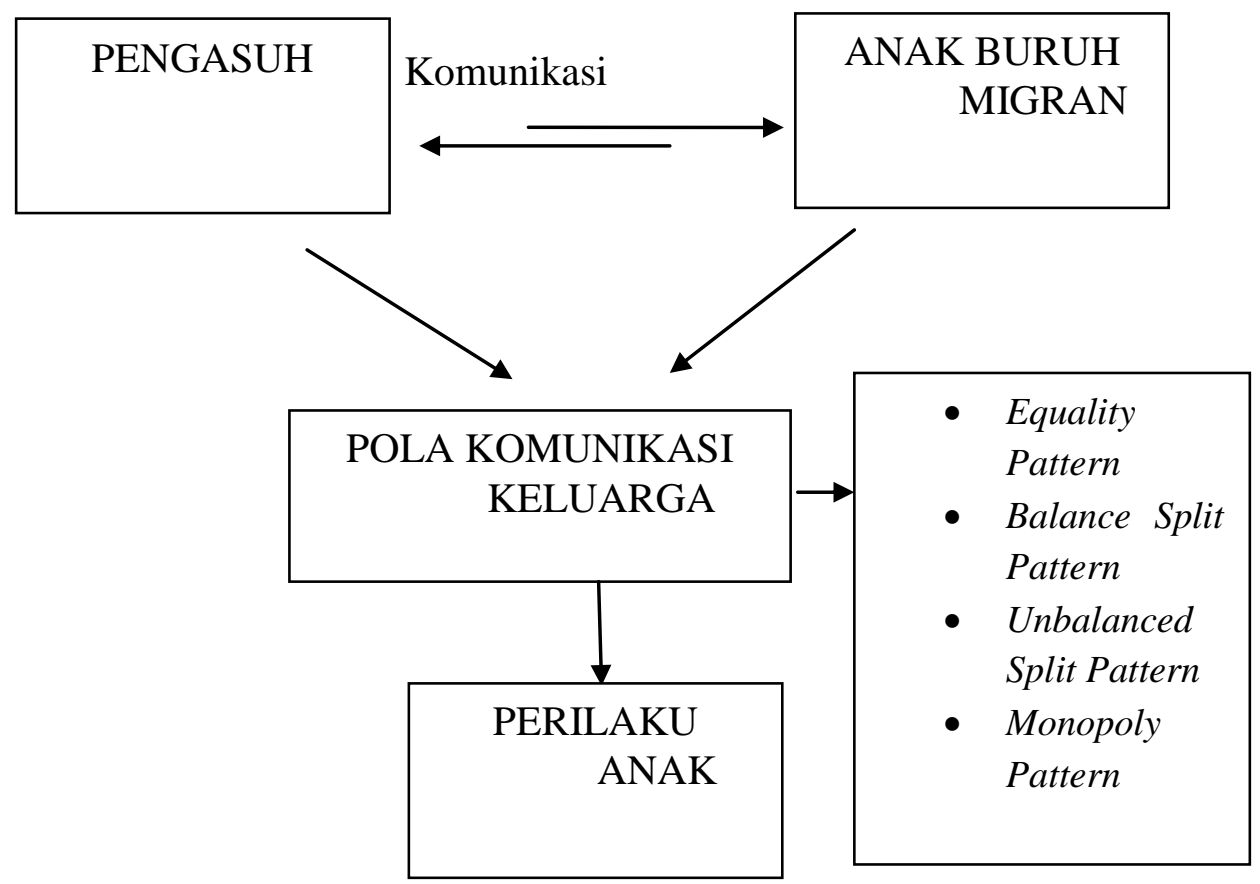

\section{Metode}

Dalam penelitian ini penulis menggunakan metode deskriptif kualitatif. Menurut Moleong (2003) penelitian kualitatif adalah metode penulisan yang menghasilkan data deskriptif berupa kata-kata tertulis atau lisan dari orang-orang dan perilaku yang diamati. Sedangkan menurut Nawawi pendekatan kualitatif dapat diartikan sebagai rangkaian kegiatan atau proses menjaring informasi, dari kondisi sewajarnya dalam kehidupan suatu objek, dihubungkan dengan pemecahan suatu masalah, baik dari sudut pandang teoritis maupun praktis. Penelitian kualitatif dimulai dengan mengumpulkan informasi-informasi dalam situasi sewajarnya, untuk dirumuskan menjadi suatu generalisasi yang dapat diterima oleh akal sehat manusia.

Sehingga metode penelitian yang penulis gunakan adalah metode deskriptif kualitatif yaitu menggunakan metode yang dirancang untuk mengumpulkan informasi tentang keadaan-keadaan nyata sekarang (sementara berlangsung) tujuan utama menggunakan jenis penelitian menggambarkan sifat suatu keadaan yang sementara berjalan pada saat penelitian dilakukan, dan memeriksa sebab-sebab dari suatu gejala tertentu atau uraian suatu keadaan sejernih mungkin tanpa ada perlakuan terhadap objek yang diteliti (Kountur, 2004). 
Pendekatan kualitatif dipilih karena peneliti ingin mendeskripsikan dan memperoleh gambaran nyata serta menggali informasi yang jelas mengenai Pola Komunikasi Keluarga Buruh Migran di Desa Pandan Wangi di Desa Pandan wangi, Kecamatan Jerowaru, Kabupaten Lombok Timur.

\section{Fokus Penelitian}

Penelitian ini akan difokuskan pada bagaimana pola komunikasi, dan perilaku anak yang ditimbulkan melalui komunikasi yang digunakan dalam keluarga.

1. Pola komunikasi yang dimaksud dalam penelitian ini adalah proses komunikasi yang mana terjadi penyampaian pesan antara (komunikator) dan penerima pesan (komunikan) yang memiliki latar belakang anak yang ditinggalkan oleh salah satu/ kedua orangtuanya. Dalam keadaan demikian, proses ini dihadapkan pada upaya penyampaian dan penerimaan sandi-sandi komunikasi yang disampaikan oleh komunikator kepada komunikan, sehingga tujuan komunikasi dalam keluarga tersampaikan dengan baik.

2. Perilaku komunikasi anak yang diterapkan dalam anggota keluarga yang tidak lengkap tanpa kehadiran salah satu orangtua/ kedua orangtuanya dalam kehidupan sehari-harinya.

\section{Informan Penelitian}

Untuk memperoleh hasil penelitian yang maksimal dibutuhkan informan yang menjawab rumusan masalah yang dibuat oleh peneliti. Dalam penelitian yang dilakukan informan juga dijadikan objek penelitian, kualitas hasil penelitian yang baik atau tidak juga ditentukan oleh informan yang ada. Oleh karena itu narasumber ini harus sesuai dan tepat seperti apa yang dituju dalam rumusan masalah yang ada di peneilitian. Dari permasalahan pola komunikasi keluarga buruh migran pada keluarga yang ada di Desa Pandan Wangi Kecamatan Jerowaru, Kabupaten Lombok Timur.

Pihak pihak yang dijadikan narasumber sebagai berikut:

$>$ Mantan buruh migran

Sebagai Narasumber untuk mengetahui pola komunikasi yang terjadi pada anak setelah berenti menjadi buruh migran.

$>$ Pengasuh anak buruh migran

Misalnya bapak/ibu yang ditinggalkan, ini menjadi hak penuh dalam mengasuh anak karena yang akan diteliti yaitu pola komunikasi keluarga antara anak dan oarangtua.

$>$ Anak buruh migran 
Untuk mengetahui yang terjadi pada anak dengan menggunakan pola asuh dan komunikasi yang diterapkan dalam keluarga.

Keluarga di luar pengasuh

Sebagai narasumber pembantu dalam mengetahui pola komunikasi keluarga yang telah dilakukan oleh keluarga buruh migran. Ini menjadi data pendukung data dari hasil penelitian.

Tokoh masyarakat

Tokoh masyarakat yang berada dilingkungan kelurga buruh migran tersebut sebagai narasumber pembantu untuk mengetahui bagaimana pola-pola komunikasi yang diketahui secara umum mengenai pola komunikasi keluarga buruh migran.

\section{Tempat dan Waktu Penelitian}

Penelitian ini dilaksanakan di Desa Pandan Wangi, Kecamatan Jerowaru, Kabupaten Lombok Timur.Pemilihan lokasi karena menjadi salah satu masalah di Desa Pandan Wangi yang belum terpecahkan, dan untuk meminimalisir tenaga kerja yang diberangkatkan dari tahun ke tahun, maka dari itu sangat menarik untuk dibahas dan mengetahui bagaimana Pola Komunikasi Keluarga Buruh Migran di Desa Pandan wangi, Kecamatan Jerowaru, Kabupaten Lombok Timur.

\section{Teknik Pengumpulan Data}

Teknik pengumpulan data menggunakan beberapa cara atau metode yang dilakukan dilapangan agar memperoleh data penelitian yang diinginkan. Teknik yang dipakai dalam proses pengumpulan data dilakukan dengan mencari sumber data primer dan sekunder. Sumber data tersebut dapat dihasilkan dari beberapa cara dibawah ini antara lain :

a). Observasi

Teknik observasi digunakan sebagai langkah awal untuk memulai sebuah penelitian, dengan melakukan pendalaman mengetahui kondisi lokasi penelitian berfungsi untuk menguatkan data primer. Observasi dapat dilakukan dengan pengamatan ataupun melakukan interaksi dengan masyarakat secara singkat. Dalam penelitian ini observasi dapat dilakukan di lingkungan Desa Pandan Wangi, Kecamatan Jerowaru, Kabupaten Lombok Timur. Pandan Wangi yang termasuk dalam kapasitas banyak dalam pengiriman buruh migran di Nusa Tenggara Barat. Observasi dilakukan hanya sekedar mengamati, 
mencatat hal-hal yang penting yang ditemui dan mendokumentasikan setiap peristiwa yang ditemui yang berkaitan dengan permasalan buruh migran.

b). Wawancara mendalam (indepth interview)

Metode wawancara mendalam digunakan untuk mendapatkan hasil penelitian dari wawancara langsung kepada Narasumber yang disini sebagai objek penelitian. Wawancara mendalam ini bertujuan untuk menerapkan pendekatan yang lebih interaksi dan intensif antara peneliti dan Narasumber guna memperoleh data primer lebih lanjut. Hasil wawancara kemudian akan di olah dengan hasil observasi atau data sekunder lainnya supaya lebih valid dan mendapatkan hasil yang maksimal.

c). Dokumentasi

Dalam penelitian peneliti juga harus melihat keadaan lokasi penelitian dengan melihat peristiwa-peristiwa yang terjadi yang berkaitan dengan penelitian dapat didokumentasikan dengan menggukan camera, rekaman suara, sehingga dapat menghasilkan foto serta rekaman suara yang dapat digunakan untuk mendukung hasil penelitian.

d). Studi pustaka

Data primer juga dapat diperoleh dari studi pustaka dengan data-data yang bersifat literatur seperti jurnal, buku atau sumber bacaan dari situs web.

\section{Teknik Analisis Data}

Teknik analisis data dalam penelitian kualitatif dapat berupa kata-kata, kalimat atau narasi, baik yang diperoleh dari wawancara maupun observasi, dalam penelitian ini peneliti menggunakan teknik analisis data menurut Miles dan Huberman yaitu analisis interaktif dengan tahap sebagai berikut :

a). Reduksi data

Merupakan proses pemilihan,menggolongkan, mengarahkan, membuang yang tidak perlu serta mengorganisasikan data dengan sedemikian rupa, setelah itu data yang dianggap penting kemudian dikumpulkan menjadi satu dan diklafikasi agar lebih spesifik.

b). Penyajian data 
Observasi, wawancara serta dokumentasi akan dianalisis dengan teori-teori. Dalam penyajian data ini seluruh data-data dilapangan berupa hasil yang telah dipaparkan sebelumnya sehingga dapat melihat komunikasi keluarga buruh migran.

c). Penarikan kesimpulan

Penarikan kesimpulan ini merupakan kegiatan penggambaran secara utuh dari objek yang diteliti pada proses penarikan kesimpulan berdasarkan penggabungan informasi yang telah disusun dalam suatu bentuk yang pas pada penyajian data. Melalui informasi tersebut peneliti dapat memaparkan kesimpulan dari sudut pandang peneliti untuk lebih mempertegas tulisan.

\section{Pembahasan}

Menurut observasi di lapangan MYS ditinggalkan oleh kedua orangtuanya karena faktor perceraian, anak ditinggalkan oleh ibu kandungnya semenjak berumur 3 bulan, setelah itu ibunya meninggalkannya ke Malaysia dan ditinggalkan oleh ayahnya ketika berumur 6 Tahun dengan tujuan negara yang sama. Anak berumur 11 tahun dan duduk di bangku kelas5 SD.Anak tinggal bersama bibiknya yaitu saudara kandung dari ayah, dalam keluarga tersebut terdiri dari paman, bibi, kakak, adik yang semuanya berjumlah 8 orang, namun perekonomian keluarga tempat anak tinggal cukup baik,rumahnya besar dan luas, anak juga memilki sebidang sawah yang ditinggalkan ayah untuknya, dan sawah tersebut dikelola oleh paman dan bibiknya.

Paman dan Bibiknyaberprofesi sebagai petani, sawahnya ditanami padi dan tembakau dan tentu segala keuangannya bersumber dari dua tanaman tersebut.Menurut ibu Emi 35 Tahun, Desa Pandan selaku tetangga dari MYS mengatakan "MYS merupakan anak yang penurut kepada orangtua, terkadang anak membantu paman dan bibiknya berkerja di sawah, namun anak tidak lupa dengan pendidikan yang harus dijalankan anak-anak pada masanya, anak yang aktif dan pandai bergaul,dan kesehariannya merupakan anak yang mandiri"

\section{Pola Komunikasi Keluarga MYS}

Peran keluarga yang memberikan peran seimbang pada setiap individu namun setiap individu memiliki peran pada otoritasnya. Bahwa dalam keluarga pasti membicarakan hal-hal yang terjadi pada setiap individu. Dalam hakekat komunikasi keluarga 
dilaksanakan dalam upaya untuk menciptakan keluarga yang saling mengenal dan saling memahami sesama anggota keluarga sehingga dari sana tercipta hubungan yang harmonis sehingga berpengaruh terhadap proses komunikasi keluarga.

Dalam keadaan keluarga Mohammad YS bahwa seorang bibik dipercaya mengasuh anak dengan baik, karena seperti diketahui banyak saudaralaki-laki dari ayah Mohammad YS yang sudah berkelurga, tetapi ayah mempercayai seorang adik perempuannya untuk membimbing anak dengan baik. Namun dilihat dari sisi seorang paman selaku kepala keluarga dari keluarga tersebut, paman lebih banyak menghabiskan waktu untuk bekerja, sehingga jarang terjadi komunikasi yang lebih intens dengan anak, begitupun dengan anak kandungnya, namun disini setiap peran keluarga memberikan peran yang seimbang pada setiap orang, didalam tersebut memberikan peran-peran yang berbeda namun tetap pada otoritasnya. Bersikap saling pengertian diterapkan dalam keluarga untuk menjaga keharmonisan dalam keluarga, saling pengertian disini mampu memahami setiap keadaan, kelebihan dan kekurangan masing-masing. Sikap saling terbuka menciptakan suasana kondusif sehingga komunikasi berjalan dengan baik.

Dalam kelaurga tersebut terjadi sikap saling pengertian dimana bibik mengambil peran untuk selalu bersikap aktif dalam keluarga karena mengetahui sisi lain dari anak yang diasuhnya, dengan selalu bisa saling memahami dengan suami, sehingga kehadiran Mohammad YS tidak dipermasalahkan dalam keluarga dan tidak dijadikan sebagai ancaman oleh anggota keluarga yang lain, oleh sebab itu bibik memiliki kepercayaan dankeahlian untuk menyelesaikan tanggung jawabnya dengan memahami pikiran dan perasaan suami, seorang bibik dapat memberikan respon lebih tepat dan lebih diterima pihak lain, dengan demikian komunikasi yang berlangsung dalam keluarga bersifat baik. Pendekatan positif seperti ini memberikan perasaan bahagia karena keinginan untuk mengasuh terpenuhi karena mengembangkan keterampilan dalam berempati pada seseorang.

Menurut (Bedell and Lenox dalam Budyatna,2015) dapat dikembangakan dengan menggunakan informasi dari dua sumber yaitu perilaku dan situasi.Perilaku merupakan refleksi perasaan dan pikiran, terdapat beberapa informasi dari perilaku orang lain, ungkapan verbal (perkataan) yang menyatakan keinginan, harapan dan peraasaan merupakan informasi perilaku yang penting untuk mengetahui pikiran dan perasaan 
dibalik perilaku seseorang. Ekspresi non verbal juga dapat menjadi petunjuk penting untuk mengetahui perasaan dan pikiran orang lain seperti tatap mata, gerak gerik. Adapun juga dengan situasi ada empat sumber informasi yang dapat digunakan untuk mengembangkan empati, siapa yang ada, aktivitas apa yang terjadi, waktu dan kapan situasi terjadi, serta dimana aktivitas itu terjadi. Dalam hal ini seorang bibik mampu mengendalikan situasi ini dengan baik sehingga komunikasi yang dijalankan ia dengan suami dan ia dengan anak-anaknya berjalan dengan baik.

Namun berdasarkan penelitian, seorang paman yaitu suami dari bibik tidak terlalu respect dalam berkomunikasi terhadap Mohammad YS, ini disebabkan karena anak bersikap pemalu di dalam keluarga dan paman tidak terlalu aktif dalam berkomunikasi terhadap anak, sehingga jarang terjadi suatu komunikasi yang intens terhadap paman dan anak. Ini disebabkan karena paman lebih banyak menghabiskan waktu disawah untuk bekerja, jadi untuk memberikan perhatian kepada Mohammad YS jarang dilakukannya. Jarangnya melakukan diskusi/dialog diantara keduanya membuat anak kurang merasa nyaman ketika berkomunikasi. Sifat paman yang kurang aktif dalam berkomunikasi membuat anak kaku ketika melakukan komunikasi dengannya.

Pada kenyataannya dialog/diskusi yang dilakukan dengan baik dapat meningkatkan saling memahami dan menerima, serta mengembangkan kebersamaan antara orangtua dan anak di dalam lingkungan keluarga. Komunikasi antar pribadi yang efektif mampu mempengaruhi emosi pihak-pihak yang terlibat dalam komunikasi itu ke dalam suasana yang nyaman, harmonis dan bukan dalam suasana yang tertekan. Dengan demikian seberapa baik seseorang dalam melakukan komunikasi dan interaksi antarpribadi dengan orang lain, dapat dilihat dari bagaimana dia mampu mencapai tujuan komunikasi secara sehat dan adil, bagaimana ia memberdayakan orang laindan bagaimana ia mampu menjaga perasaan orang lain dan harga diri orang lain (Attayamini Rahmah,2014).

Dalam hal ini anak mengetahui kondisi yang sebenarnya,anak di dalam keluarga tidak terlalu berekspresi dalam berkomunikasi tidak seperti layaknya anak kepada orangtua pada biasanya, paman terlihat disegani oleh anak dan jarang berkomunikasi, dengan hal ini terjadi tekanan pada emosi anak untuk melakukan komunikasi terhadap paman, sehingga anak tidak pernah melakukan komunikasi/bercerita di malam hari, seperti menceritakan kegiatan-kegiatan waktu di sekolah. Adapunanak melakukan komunikasi 
dengan bibik terlihat canggung dan tidak lepas dalam berkomunikasi, anak melakukan komunikasi jika anak sangat memerlukan atau membutuhkan sesuatu yang sifatnya sangat penting, dengan itu anak meminta dengan baik kepada bibiknya. Pembagian peran dalam kelaurga ini tentu bersifat tradisional.

Perilaku tertutup pada anak membuat orangtua tidak mengetahui bagaimana perasaan yang sebenarnya yang dialami anak, perasaan malu tentu membuat anak kurang nyaman dalam kondisi yang sebenarnya. Tetapi dalam lingkungan bermain perilaku anak sangat berbalik dengan kondisi di dalam keluarga, dalam lingkungan bermain anak terlihat sangat aktif dalam berkomunikasi bahkan anak mempunyai sifat yang ingin didengar ketika bercerita dengan teman-temannya hal itu menunjukkan bahwa di dalam keluarga terjadi tekanan emosi dalam berkomunikasi dengan keluarga, tidak pada suasana tegang dan terlepas dari suatu perasaan canggung dan malu-malu terhadap orangtua dalam melakukan suatu komunikasi.

Namun melihat kondisi seperti itu semandiri apapun anak pasti akan membutuhkan peran kedua orangtua yaitu paman dan bibik untuk selalu membantu dan membimbing dalam menentukan jalan hidupnya kedepan, dan tentu semua oranagtua menginginkan yang terbaik untuk anak-anaknya.Berdasarkan penjelasan di atas menunjukkan dan mengarah kepadapola komunikasi seimbang terpisah (Balance Split Pattern) dimana kesetaraan hubungan tetap terjaga namun dalam pola ini tiap orang memiliki daerah kekuasaan yang berbeda dari yang lainnya, seperti pembagian peran seorang bibik mampu dipercaya dalam mengurus dan membimbing anak, dan paman dipercaya untuk urusan bisnis untuk mencari nafkah.

\section{Perilaku Komunikasi Anak dalam Komunikasi Kelurga}

Perilaku merupakan perbuatan atau tingkah laku seseorang yang bersifat kongkrit atau nyata baik secara reflek maupun secara sadar, baik jasmaniah maupun rohaniah. Tingkah laku adalah fungsi dari situasi dan hal-hal yang mendahului situasi tersebut. Pembentukan perilaku tidak akan taerjadi dengan sendirinya meskipun perilaku tersebut dibawa sejak lahir namun tetapi perilaku dalam diri sendiri dapat terbentuk melalui pengalaman-pengalaman dan interaksi manusia dengan objek-objek tertentu secara berulang-ulang dan perilaku pada diri seseorang baik dari dalam diri seseorang maupun luar dirinya. Namun menurut para ahli, perilaku seseorang banyak di pengaruhioleh 
kondisi dalam rumah tangga dimana ia bernaung bahkan para ahli mengatakan bahwa kepribadian seseorang telah terbentuk dari ia didalam kandungan sang ibu.

Arah lebih lanjut pembentukan kepribadian di tentukan dalam kehidupan keluarga. Jika dia dibesarkan dalam rumah tangga yang bahagia maka perilaku seseorang akan bersifat baik misalnya dalam pembentukan sifat. Sifat yang positif seperti ramah, sabar, gembira, kerjasama, toleran, tidak egois dan memiliki rasa simpatik. Sebaliknya jika seseorang dibesarkan dalam keluarga yang kurang bahagia, sukar diharapkan orang tersebut menumbuhkan kepribadian yang positif.

Namun berdasarkan penelitian pada keluarga Mohammad YS yang ditinggalkan oleh kedua orangtuanya keluar negeri dan tinggal pada pengasuhan orangtua paman dan bibik. Perilaku yang ditimbulkan mempunyai empati yang baik terhadap sesama, mampu bekerjasama dengan anggota keluarga yang lain. Bekerjasama terhadap sesama merupakan suatu perilaku yang dibentuk anak dari kebiasaan sehari-hari dan dibentuk oleh keluarga, rasa empati terhadap sesama tentu mendorong orang untuk mampu memahami dan melihat permasalahan dari sudut pandang yang sesuai agar dapat menempatkan diri dan memberikan respon yang sesuaidengan permasalahan tersebut. Seperti contohBibik membelikan sepeda bekas kepada anak, supaya anak tidak merasa minder ketika bermain dengan teman-teman yang rata-rata temannya mempunyai sepeda,dan anakpun merasa senang.

Oleh karena itu empati sangat diperlukan dalam membantu oranglain dalam mendapatkan sebuah rasa nyaman dan tenang dalam mengahadapi kondisi tersebut. Hubungan positif antar sesama akan menimbulkan perasaan nyaman dan aman, setiap emosi yang keluar dari dalam diri seseoarng dalam bentuk ekspresi wajah, nada suara dan juga perilaku, dalam kondisi ini anak sudah memperilhatkan bentuk perilaku terhadap kepekaan terhadap suatu kondisi dimana ia tinggal.

Salah satu yang mempengaruhi empati adalah komunikasi (Goleman,1997), pengungkapan empati dipengaruhi oleh (bahasa) yang digunakan seseorang, bentuk dari bahasa digunakan orangtua pada anak sangat baik dan sopan dalam pengucapan, seperti panggilan Tatik(anak laki-laki) yang bentuknya sopan, halus dan mudah diterima oleh anak terutama masyarakat di Desa Pandan Wangi. Bahasa yang digunakan dan penempatan bahasa yang benar tentu akan membuat anak cepat menerima apa yang 
diucapkan oleh sang bibik. Pesan yang disampaikan tentu akan mudah di terima oleh anak, dan komunikasi yang di lakukan tentu berhasil karena pesan yang disampaikan mudah di terima, dan memberikan respon yang baik sesuai dengan tujuan dalam berkomunikasi.

Tabel 4.7. Bentuk Empati di Pengaruhi oleh BahasaMYS

\begin{tabular}{|c|c|c|c|c|c|c|c|c|}
\hline No & & Situasi & & Penyampaian pesan & Resp & ons & & Feedback \\
\hline 1 & Bibik & \begin{tabular}{l}
\multicolumn{2}{r}{ menyuruh } \\
anak untuk \\
pergi \\
menggiling \\
kopi di \\
warung \\
dekat \\
dengan \\
jalan, \\
sekitar 100 \\
meter dari \\
rumah \\
\end{tabular} & $\begin{array}{l}\text { "Mat, } \\
\text { (anak } \\
\text { (Bibik }\end{array}$ & $\begin{array}{l}\text { heleran kupi nu aok tatik } \\
\text { laki-laki)? priak Tuakn } \\
\text { melet ngupi, aok tatik } \\
\text { sekali". } \\
\text { meminta anak pergi } \\
\text { menggiling kopi dan } \\
\text { Bibikmenggunakan nada } \\
\text { yang lembut dan bahasa } \\
\text { yang sopan) }\end{array}$ & $\begin{array}{l}\text { "Aok" } \\
\text { (anak }\end{array}$ & $\begin{array}{l}\text { mer } \\
\text { esp } \\
\text { on } \\
\text { den } \\
\text { gan } \\
\text { baik } \\
\text { ) }\end{array}$ & Bibik & $\begin{array}{l}\text { memberikan uang } \\
\text { dan kopi, dan } \\
\text { menyuruh anak } \\
\text { untuk ber hati- } \\
\text { hati. } \\
\text { menunjukkan } \\
\text { perhatiannya } \\
\text { kepada anak) }\end{array}$ \\
\hline
\end{tabular}

Proses perkembangan empati pada diri seseorang yaitu pola asuh (Franz dalam Koestner, 1990) menemukan adanya hubungan yang erat dengan pola asuh diinterprestasikan sebagai besarnya interaksi antara ibu dan anak dan refleksi kelembutan responsivitas dan penerimaan terhadap perasaan anak yang semuanya berhubungan dengan perilaku prososial.Ibu yang puas akan perannya akan mampu menciptakan anak yang memiliki empatiyang tinggi,hal ini karena ibu yang memiliki keyakinan akan kemampuannya dan tidak cemas dalam pengasuhan anak. Ibu yang mempunyai kepercayaan lebih juga dapat memberikan perhatian atau lebih peduli perasaan anak.

Hal tersebut juga dilakukan oleh pengasuh/orangtua dari Mohammad YS terlihat dari cara memperlakukan anak dalam kehidupan sehari-harinya yang tidak memprioritaskan salah satu anak-ankanya dalam memberikan perhatian antara satu dengan yang lain, ada juga proses perkembangan empati berdasarkan dari jenis kelamin, berdasarkan beberapa penelitian diketahui bahwa perempuan memiliki empati yang tinggi dibandingkan dengan laki-laki. Karakteristik yang di atribusikan pada perempuan dibanding laki-laki adalah kecenderungan berempati.Perempuan kecendrungan berempari tinggi dari pada laki-laki. 
Persepsi stereotip tersebut didasarkan pada kepercayaan bahwa perempuan lebih bersifatmemelihara dan lebih berorientasi interpersonal dibandingkan laki-laki (Parsons \& Bales dalam Eisenberg \&Strayer 1987) berupa cerita hipotetik yang diajukan untuk melihat respon empatik dalam merespon secara verbal keadaan pada orang lain.Dalam hal ini terlihat sama bahwa bibik mempunyai empati yang lebih ringgi daripada paman. Terlihat dari keseharian yang dilakukannya di dalam keluarga seperti yang telah di contohkan sebelumnya.

Mohammad YS merupakan anak yang mempunyai perilaku kreatif dan mempunyai orientasi wirausaha, dia merupakan anak yang cukup kreatif dibandingkan dengan anak-anak sebayanya, kreatif dalam arti dia belajar membuat layangan, layanglayang tersebut dia jual kembali ke temen-temannya, dia mempunyai perilaku tersebut karena dipengaruhi oleh faktor lingkungan di dalam keluarga, yang pengasuhnya bergelut dalam usaha tembakau, selain sebagai petani. Anak terbiasa melihat proses interaksi penjualan tembakau yang dilakukan oleh paman dan bibi selaku orangtua. Anak mengetahui hal tersebut dan terlibat langsung dalam proses pembelian dan penjualan tembakau. Jadi perilaku dan sifat dari anak tertanam karena terbiasa melihat suatu transaksi yang terjadi, tentu hal ini mempunyai pengaruh besar terhadap diri anak. Dengan itu tertanam sifat mandiri, dengan bisa menghasilkan uang sendiri, dengan usia yang belum matang untuk berusaha. Memanfaatkan situasi dengan menghasilkan sesuatu yang bermanfaat untuk dirinya.

Salah satu penyebab orientasi wirasuaha pada anak karena pada dasarnya uang saku yang di berikan bibik per/hari merasa tidak cukup untuk anak, uang belanja anak per/hari di jatahkan sebesar Rp 5.000. Oleh karena itu anak tidak pernah minta uang kepada bibiknya selepas pulang dari sekolah, tidak seperti anak-anak yang lain, yang setiap hari bisa di totalkan sampai Rp 15.000-20.000/ hari. Dengan perasaan yang tidak cukup maka anak berinisatif dalam memanfaatkan hal-hal kecil seperti menjual layangan, menjual kartu berhadiah, dll.

David McClelland dalam Budyatna (2015) juga menemukan bahwa orang dengan $\mathrm{n}$-ach tinggi terbentuk dalam pendidikan keluarga, kebanyakan mereka pada usia 6-8 tahun sudah diajari mandiri, membuat pilihan-pilihan dan mengerjakan sesuatu tanpa bantuan orang lain, (n-ach) ini merupakan skor kebutuhan untuk berprestasi. Perilaku 
seperti ini sangat positif untuk menunjukkan jati diri sebagai anak dan tentu sangat mendukung untuk kemajuan anak dalam menjalani proses berkembangnya pola pikir anak.Namun pada perlaku dalam sehari-hari ketika bermain dengan teman-temennya ia memiliki perilaku yang mudah emosi di bandingkan dengan teman-temannya yang lain.

\section{Narasumber 2}

\section{Pola Komunikasi Keluarga (RRA)}

Keluarga pasti membicarakan hal-hal yang terjadi pada setiap individu. Dalam hakekat komunikasi keluarga dilaksanakan dalam upaya untuk menciptakan keluarga yang saling mengenal dan saling memahami sesama anggota keluarga sehingga dari sana tercipta hubungan yang harmonis sehingga berpengaruh terhadap proses komunikasi keluarga.

Dalam kondisi tersebut, seorang anak yang di tinggalkan oleh Ayahnya ke luar negeri membuat komunikasi anak semakin menyempit, dikarenakan jarang terjadi komunikasi yang intens pada kehidupan sehari-hari, tidak seperti keluarga yang normal pada umumnya. Lantas yang sering berkomunikasi sehari-hari dengan anak yaitu ibu, ibu yang selama ini menemai anak dalam kehidpan sehari-hari, peran ibu dalam kehidupan sehari-hari salah satunya yaitu ibu yang mennyediakan kebutuhan anak-anak. Pada dasarnya kebutuhan seseorang meliputi kebutuhan fisik, psikis, sosial dan spiritual.

Kebutuhan fisik merupakan kebutuhan makan, minum, pakaian, tempat tinggal, dan kebutuhan psikis yaitu kebutuhan rasa aman, kasih sayang, di terima dan di hargai, sedangkan kebutuhan sosial akan di peroleh anak dari kelompok di luar lingkungan keluarganya. Kebutuhan spiritual, adalah pendidikan yang menjadikan anak mengerti kewajiban kepada TuhanNya, orangtuanya dan sesama saudaranya. Dalam pendidikan spiritual juga mencakup mendidik dan berakhlak mulia, mengerti agama dan bergaul dengan teman-temannya dan menyayangi sesama saudaranya menjadi tanggung jawab ayah dan ibu. Dalam memahami kebutuhan psikis anak serorang ibu harus menciptakan situasi yang aman bagi putrinya. Ibu di harapkan dapat membantu anak apabila mereka menemui kesulitan-kesulitan. Perasaan yang aman yang diperoleh dari rumah akan dibawa ke luar rumah, artinya anak tidak mudah cemas dalam mengahadapi masalahmasalah yang timbul. 
Seorang ibu harus mampu menciptakan hubungan atau ikatan emosional dengan anaknya. Kasih sayang yang diberikan ibu terhadap anaknya akan menimbulkan berbagai perasaan yang dapat menunjang kehidupannya dengan orang lain. Cinta kasih yang diberikan ibu pada anak akan mendasari bagaimana sikap anak terhadap orang lain. Seorang ibu yang tidak mampu memberikan cinta kasih pada anak-anaknya akan menimbulkan perasaan ditolak, perasaan ditolak ini akan berkembang menjadi perasaan dimusuhi. Anak dalam perkembangannya akan menganggap bahwa orang lainpun seperti ibu. Sehingga tanggapan anak terhadap orang lain juga akan bersifat memusuhi, menentang atau agresi.

Seorang ibu yang mau mendengarkan apa yang dikemukakan anaknya, menerima pendapatnya dan mampu menciptakan komunikasi secara terbuka dengan anak, dapat mengembangkan perasaan dihargai, diterima dan diakui keberadaanya. Untuk selanjutnya anak akan mengenal apa arti hubungan di antara mereka dan akan mewarnai hubungan anak dengan lingkungannya. Anak akan tahu bagaimanacara menghargai orang lain, tenggang rasa dan komunikasi, sehingga dalam kehidupan dewasanya anak tidak akan mengalami kesulitan dalam bergaul dengan orang lain.

Namun pada kenyataannya anak yang ditinggalkan oleh Ayahnya ke luar negeri membuat hubungan ibu dan anak kurang normal, menurut wawancara dari tetangganya yang bernama Ibu Raudah 35 Tahun, Desa Pandan wangi mengatakan bahwa "anak sering melawan perintah orangtua, anak sering bertengkar karena berbeda pendapat dengan Ibunya, mereka kelahi terkadang gara-gara uang, karena anaknya terlalu boros, seperti contohproses begelantang(pengikatan tembakau sebelum dinaikkan ke oven) kalau ibunya membutuhkan tenaga begelantang, anak tidak tulus menolong ibunya, anak harus di bayar sesuai dengan harga normal yang di tarif oleh orang-orang pekerja tembakau, untuk menyelesaikan proses begelantang tersebut, dalam hitungan 5 gelantang di hargai dengan Rp 1000 maka hitungan yang di peroleh sang anak juga harus seperti seimbang dengan itu, tidak seperti anak-anak lain yang membantu ibunya tanpa imbalan yang harus di terima".

Dalam permasalahan ini ibu kurang di hargai oleh anak, anak sering melawan perintah orangtua, adapun terkadang juga ibu sering mengeluarkan kata-kata yang kurang 
sopan terhadap anaknya, bahasa yang di gunakan juga sangat berpengaruh terhadap stimulus anak dalam menerima sesuatu dengan baik seperti contoh kata "nyentet" kata tersebut di katakan tidak sopan karena julukan yang kurang baik terhadap panggilan anak perempuan. Kata-kata seperti itu sulit di terima sang anak sehingga anak memberikan rasa kurang nyaman.Dalam hal ini hendaknya orang tua harus dapat menjadi contoh yang positif bagi anak-anaknya. Anak akan mengambil nilai-nilai, sikap maupun perilaku orang tua, tidak hanya apa yang secara sadar diberikan pada anaknya misal melalui nasehat-nasehat, tetapi juga dari perilaku orang tua yang tidak disadari.

Sering kita lihat banyak orangtua yang menasehati anaknya tetapi mereka sendiri tidak melakukannya. Hal ini akan mengakibatkan anak tidak sepenuhnya mengambil nilai, norma yang ditanamkan. Jadi, untuk melakukan peran sebagai model, maka ibu sendiri harus sudah memiliki nilai-nilai itu sebagai milik pribadinya yang tercermin dalam sikap dan perilakunya. Hal ini penting artinya bagi proses belajar anak-anak dalam usaha untuk menyerap apa yang ditanamkan.Dalam hal ini anak kurang dekat dengan ibunya, anak jarang terbuka dengan ibu, anak jarang melakukan komunikasi dan berbagi cerita dan pengalaman dengan ibu, ketika anak kelahi dengan teman-teman bermainnya, anak tidak menceritakan masalah yang dihadapinya, anak menyelesaikan masalahnya dengan sendiri.

Dalam konflik yang sering terjadi antara anak dan ibu, seorang ibu juga jarang berbagi cerita terhadap permasalahan yang terjadi kepada dirinya, peran suami di dalam keluarga kurang menonjol, karena peran suami hanya dalam pemenuhan kebutuhan ekonomi, seorang istri jarang berbagi informasi, jarang mengadu kepada suaminya apa yang terjadi pada anaknya. Jadi dalam menentukan suatu keputusan sang istri tidak memerlukan peran suami. Jarang adanya diskusi mengenai anaknya, begitupun sebaliknya dengan ayah jarang melakukan komunikasi. Karena ayah bisa langsung melakukan komunikasi dengan anak melalui telepon. Jadi ketika anak meminta sesuatu kepadanya, anak bercerita kepada ayahnya dan sering sekali ayahmengabulkan permintaan sang anak, seperti pemberian HandPhone kepada anak, padahal dalam hal tersebut sang isteri tidak ingin membelikannya, tetapi sang ayah sudah mengirimkan uang, dan ayah mengasih tau anaknya, Padahal niat isteri supaya anak tidak terganggu dengan handphone. 
Tujuannya ibu supaya fokus terhadap pendidikan dan tidak memikirkan apapun selain sekolah. Dalam hal ini secara tidak langsung ayah memberikan suport dari belakang, sehingga anak menganggap ibunya salah dalam pengasuhan dirinya sehingga terjadi penolakan terhadap anak, adapun Ayah yang dekat dengan anakdan bisa memenuhi kebutuhan anak. Ketika anak meminta uang kepada ibunya dengan kebutuhan untuk membeli pulsa, otomatis ibunya tidak memberikan hal tersebut, tetapi anak berinisiatif sendiri untuk langsung untuk meminta kepada Ayahnya dan tentu Ayah mengabulkan permintaan anak dan di kirimkan pulsa sebesar 100.000, dalam hal ini suami tidak mengkomunikasikan hal tersebut terlebih dahulu kepada isteri.

Dalam keluarga ini menerapkan pola komunikasi keluarga yang mengarah kepada komunikasi tak seimbang terpisah (Unbalanced Split Pattern) Dalam hubungaan ini dalam keluarga si suami mendominasi. Maka dari itu, satu orang ini secara teratur mengendalikan hubungan dan hampir tidak pernah meminta pendapat antara kedua belah pihak yaitu jarang meminta pendapat kepada anggota keluarga yang lain. Sedangkan si isteri yang dikendalikan membiarkannya untuk memenangkan argumentasi ataupun membuat keputusan.

\section{Perilaku Komunikasi Anak dalamKomunikasi Kelurga}

Pengasuhan merupakan tanggung jawab utama orangtua, sehingga sangat disayangkan bila masa inimasih ada orangtua yang menjalani peran orangtua tanpa kesadaran pengasuhan.Pengasuhan anak dipercaya memiliki dampak terhadap perkembangan individu. Pengasuhan anak akan memberikan pengasuhan yang lebih baik apabila ayah dan ibu menjalankan pengasuhan bersama, yaitu bila orangtua bersikap saling mendukung dan bertindak sebagai salah satu tim yang bekerjasama, bukan saling bertentangan. Melalui observasi dan pengamatan di lapangan orangtua Ayah dan ibu belum mampu bekerjasama dalam mengurus anak. Kontrol yang dilakukan oleh Ayah dan Ibu belum maksimal dalam hal ini. Kontrol dalam hal ini diartikan dalam penekanan terhadap adanya batasan-batasan terhadap perilaku yang disampaikan dengan jelas kepada anak, misalnya membantu perkerjaan rumah sebagaimana diminta oleh orangtua.

Perilaku merupakan perbuatan atau tingkah laku seseorang yang bersifat kongkrit atau nyata baik secara reflek maupun secara sadar, baik jasmaniah maupun rohaniah. 
Tingkah laku adalah fungsi dari situasi dan hal-hal yang mendahului situasi tersebut. Pembentukan perilaku tidak akan taerjadi dengan sendirinya meskipun perilaku tersebut dibawa sejak lahir namun tetapi perilaku dalam diri sendiri dapat terbentuk melalui pengalaman-pengalaman dan interaksi manusia dengan objek-objek tertentu secara berulang-ulang dan perilaku pada diri seseorang baik dari dalam diri (intern) seseorang maupun luar dirinya (ekstern).

Namun menurut para ahli, perilaku seseorang banyak di pengaruhi oleh kondisi dalam rumah tangga dimana ia bernaung bahkan para ahli mengatakan bahwa kepribadian seseorang telah terbentuk dari ia di dalam kandungan sang ibu. Arah lebih lanjut pembentukan kepribadian di tentukan dalam kehidupan keluarga. Jika dia dibesarkan dalam rumah tangga yang bahagia maka perilaku seseorang akan bersifat baik misalnya dalam pembentukan sifat. Sifat yang positif seperti ramah, sabar, gembira, kerjasama, toleran, tidak egois dan memiliki rasa simpatik. Sebaliknya jika seseorang dibesarkan dalam keluarga yang kurang bahagia, sukar di harapkan orang tersebut menumbuhkan kepribadian yang positif.

Namun berdasarkan penelitian yang di lakukan pada keluarga buruh migran yang di tinggalkan oleh ayahnya memiliki kelakuan yang tidak baik, anak dalam pengasuhan ibu memiliki perilaku yang tidak baik seperti sering berkata kasar, sering menggunakan nadanada yang keras, karena ini juga yang diterapkan oleh seorang ibu kepada anaknya yang terkadang ibu tidak menyadari dampak negatif dari cara berkomunikasi dengan anak, cara menyampaikan tentu akan berpengaruh kepada bagaimana orang menerimanya. Walaupun ibu dalam kesehariannya sering memperingati anak, memberikan nasihatnasihat, tetapi orangtua tidak memikirkan dan menyadari bagaimana cara menyampaikan kepadaanak supaya anak bisa menerima apa yang diinginkan untuk perubahan anaknya.

Perilaku anak masih ditempuh dengan menerapkan model dari orangtua, anak akan mengambil nilai-nilai, sikap maupun perilaku orang tua, tidak hanya apa yang secara sadar diberikan pada anaknya misal melalui nasehat-nasehat, tetapi juga dari perilaku orang tua yang tidak disadari. Sering kita lihat banyak orangtua yang menasehati anaknya tetapi mereka sendiri tidak melakukannya. Hal ini akan mengakibatkan anak tidak sepenuhnya mengambil nilai, norma yang ditanamkan. Jadi, untuk melakukan peran sebagai model, maka ibu sendiri harus sudah memiliki nilai-nilai itu sebagai milik 
pribadinya yang tercermin dalam sikap dan perilakunya. Hal ini penting artinya bagi proses belajar anak dalam usaha untuk menyerap apa yang ditanamkan. Padahal salah satu kewajiban ibu yang diberikan kepada anak salah satunya yaitu memenuhi kebutuhan psikis yaitu kebutuhan rasa aman, kasih sayang, di terima dan di hargai.

Perekembangan Anak menuju tahap remaja inilah seorang semestinya mendapat bimbingan penuhdari orangtua yang lebih dahulu berpengalaman dari pada anaknya.Pemahamantentang nilai-nilai,norma-norma,dan aturan-aturan yang ada dalam masyarakat harusdisosialisasikan secara intensif. Namun bilaorang tua terutama ayah sebagai sosok sentral telah hilang dari pendampingan anak maka anak kehilangan sosok "pengarah" yang mengakibatkan terjadinya penyimpangan, dimanahubungan antara anak dengan orang tua ibu menjadi tidak harmonis, danmenjadikan keluarga tidak berkualitas. Kehidupan orang tua (rumah tangga)yang tidak berkualitas disebabkan oleh hidup terpisah dan akan menciptakan penyimpanganterhadap anaknya, hal tersebut dapat disebabkan karena hal-hal sebagai berikut :

1. Anak kurang mendapatkan perhatian, kasih sayang dan tuntunan pendidikanorang tua, terutama bimbingan ayah, karenaAyah berada di luar negeri.

2. Kebutuhan fisik maupun psikis anakremaja menjadi tidak terpenuhi.Keinginan dan harapan anaktidak bisa tersalur dengan memuaskan, atau tidakmendapatkankompensasinya.

3. Anaktidak pernah mendapatkan latihan fisik dan mental yang sangat dibutuhkan untuk hidup bersusila. Mereka tidak dibiasakan dengan disiplin dan kontroldiri yang baik (Kartono, 2008).

Sebagai akibat ketiga bentuk pengabaian di atas anak menjadi bingung, risau,sedih, malu, sering diliputi perasaan dendam dan benci sehingga anak akan menjadikacau dan liar dan dikemudian hari akan mencari kompensasi bagi kerisauan batinsendiri diluar lingkungan keluarga. Berdasarkan wawancara yang di lakukan oleh Mukmin 40 tahun, desa pandan juga mengatakan bahwa "perilaku anak saya ketika saya pulang dari luar negeri yaitu anak baik dan sopan, menghormati patuh kepada ibunya, saya tidak pernah memberikan kebutuhan anak melalui saya, saya hanya melakukan komunikasi dengan ibunya, dan ibunya yang mengatur segala kebutuahannya. Berdasarkan wawancara dari istri dari Mukmin yaituMuhani 38 tahun "saya jarang memarahi anak, tetapi pengawasan juga tetap saya lakukan, seperti kegiatan yang di lakukan sehari-hari dan anakpun dekat dengan saya dan sering menceritakan sesuatu yang 
terjadi pada dirinya seperti ada masalah dan kebutuhan-kebutuhan tetap di komunikasikan dengan baik". Jadi dapat disimpulkan bahwa perilaku anak tergantung dari bagaiamana orangtua menerapkan pengasuhan sehari-hari terhadap anak.

\section{Gambaran Umum Keluarga MFB (10 Tahun)}

Menurut observasi di lapangan, anak tinggal dengan neneknya, anak berumur 10 Tahun dan duduk di bangku kelas 4 SD dari hasil wawancara dengan bapak Zaenal abidin, 51 Tahun selaku kepala dusun pandan mengatakan "anak ditinggalkan oleh ibunya ke Malaysia semenjak anak berumur 4 tahun setelah orangtuanya bercerai, ia tinggal bersama dengan Ayahnya, namun setelah beberapa bulan bercerai Ayahnya menikah lagi dan tentu anak mempunyai ibu tiri,waktu itu anak jarang terkontrol sehingga anak di asuh dan tinggal dengan neneknya yang bernama Sri ulam yang berumur berkisar 80 tahun, namun dalam pengawasan dalam mengasuh anak kurang baik karena faktor usia yang sudah tua, tentu dalam pengasuhannya tidak sebaik mungkin, seperti diketahui anak mengalami penyakit kulit dikarenakan karena jarang mandi, banyak saudara dari Ayahnya sering mengingatkan sang ayah untuk mengasuh dan mengurus anak dengan baik namun tidak ada sikap dan perubahan maupun tindakan yang dilakukan ayah untuk anaknya, sampai saat ini anaknya di biarkan tinggal bersama neneknya (wawancara tanggal 23 April 2017)

\subsubsection{Pola Komunikasi Keluarga MFB}

Peran keluarga yang memberikan peran seimbang pada setiap individu namun setiap individu memiliki peran pada otoritasnya. Bahwa dalam keluarga pasti membicarakan hal-hal yang terjadi pada setiap individu. Dalam hakekat komunikasi keluarga dilaksanakan dalam upaya untuk menciptakan keluarga yang saling mengenal dan saling memahami sesama anggota keluarga sehingga dari sana tercipta hubungan yang harmonis dan berpengaruh terhadap proses komunikasi keluarga.

Dalam kondisi tersebut, seorang anak yang di tinggalkan oleh Ibunya ke luar negeri membuat komunikasi anak semakin menyempit, dikarenakan jarang terjadi komunikasi yang intens pada kehidupan sehari-hari, tidak seperti keluarga yang normal pada umumnya. Lantas yang sering berkomunikasi sehari-hari dengan anak yaitu nenek, nenek yang selama ini menemai anak dalam kehidupan sehari-hari karena anak dititipkan 
kepada nenek, karena Ayah memutuskan itu ketika Ayah menikah lagi namun peran Ayah dalam perawatan anaknya di jelaskan oleh (Hard,2002).

a. Sebagai orang yang memenuhi kebutuhan finansial anak untuk membeli segala keperluan anak (economic provider)

b. Ayah sebagai teman bagi anak termasuk teman bermain (friend and playmate)

c. Ayah memberi kasih sayang dan merawat anak(caregiver)

d. Ayah berperan memberikan contoh tauladan yang baik (teacher and role models)

e. Ayah berperan memantau/mengawasi dan menegakkan aturan disiplin(monitor and disiplinarian)

f. Ayah berperan sebagai pelindung dari resiko bahaya (protector)

g.Ayah berperan membantu mendampingi dan membela anak jika mengalami kesulitan/masalah (advocate)

h. Ayah berperan mendukung keberhasilan anak (resource)

Berdasarkan uraian di atas bahwa dapat disimpulkan bahwa ayah mempunyai karakteristik perilaku pengasuhan yang khas. Selain tugas pokok sebagai penyediaam kebutuhan anak, ayah mempunyai perilaku pengasuhan yang khas antara lain : interaksi ayah-anak berorientasi pada komunikasi yang mendekatkan gerak dan bermain,membantu anak bereksplorasidan menyukai tantangan, ayah mampu mengajarkan sikap artestif, kebijaksanaan pengambilan keputusan, ayah merupakan pendisiplinan yang tegas, dan ayah merupakan peletak dasar kemampuan intelektual anak.

Namun demikian penelitian yang dilakukan pada keluarga buruh migran yang ditinggalkan oleh Ibu keluar negeri dan diberikan kepada pengasuhan Ayah memberikan dampak yang sangat besar terhadap perkembangan anak. Ayah jarang melakukan komunikasi dengan anak, memberikan perhatian serta dalam pemenuhan kebutuhan psikis anak.Hasil penelitian yang di lakukan di keluarga buruh migran yang ditinggalkan oleh ibunya ke luar negeri memberikan pengaruh besar seperti, anak dititipkan ke nenek karena dipengaruhi oleh istri barunya yang tidak terlihat peduli terhadap anak tirinya, di lihat dari ibu memperhatikan anak-anaknya yang lain, seperti memberikan makan dan perhatian di waktu sore ketika anak sedang bermain di lingkungan rumah dengan cara di suapi sambil bermain. Bahkan selama kegiatan anak berlangsung, ibu tidak pernah 
menanyakan/berkomunikasi dengan anak tiri dan fokus memperhatikan anaknya yang sedang bermain sambil memberikan anaknya makan.

Menurut wawancara dari kakak misan dari Mohammad Farel yang bernama Yogi, 25 Tahun, Desa Pandan juga mengatakan bahwa "bapaknya jarang menanyakan kabar, jarang memperhatikan anaknya dan saya sangat kasihan kepada anak yang tidak mendapatkan kasih sayang ayahnya, dan ibunya juga cuek kepada anak, namanya juga berbeda ibu, bedalah cara di perlakukan dengan anak kandungnya”. Anak tidak terbuka dalam berkomunikasi dengan orangtuanya, seperti anak tidak pernah menayakan ke Ayahnya ketika Ayahnya jarang menjenguk, begitupun sebaliknya, keterbukaan informasi yang diberikan Ayah kepada anak terlihat kurang, karena ayah tidak menceritakan kenapa jarang menjenguk, serta jarang menceritakan kegiatannya kepada anak.

Berdasarkan uraian di atas komunikasi yang terjadi pada keluarga buruh migran yaitumenerapkan pola komunikasi keluarga yang mengarah kepada komunikasi tak seimbang terpisah (Unbalanced Split Pattern)satu orang dalam keluarga si istri mendominasi. Maka dari itu, satu orang ini secara teratur mengendalikan hubungan dan hampir tidak pernah meminta pendapat antara kedua belah pihak yaitu Ibu jarang meminta pendapat kepada anggota keluarga yang lain. Sedangkan si suami yang dikendalikan membiarkannya untuk memenangkan argumentasi ataupun membuat keputusan.

\subsubsection{Perilaku Komunikasi Anak dalam Komunikasi Keluarga}

Perilaku merupakan perbuatan atau tingkah laku seseorang yang bersifat kongkrit atau nyata baik secara reflek maupun secara sadar, baik jasmaniah maupun rohaniah. Tingkah laku adalah fungsi dari situasi dan hal-hal yang mendahului situasi tersebut. Pembentukan perilaku tidak akan taerjadi dengan sendirinya meskipun perilaku tersebut dibawa sejak lahir namun tetapi perilaku dalam diri sendiri dapat terbentuk melalui pengalaman-pengalaman dan interaksi manusia dengan objek-objek tertentu secara berlang-ulang dan perilaku pada diri seseorang baik dari dalam diri (intern) seseorang maupun luar dirinya (ekstern). Namun menurut para ahli, perilaku seseorang banyak di pengaruhi oleh kondisi dalam rumah tangga dimana ia bernaung bahkan para ahli mengatakan bahwa kepribadian seseorang telah terbentuk dari ia di dalam kandungan 
sang ibu. Arah lebih lanjut pembentukan kepribadian di tentukan dalam kehidupan keluarga. Jika dia dibesarkan dalam rumah tangga yang bahagia maka perilaku seseorang akan bersifat baik misalnya dalam pembentukan sifat. Sifat yang positif seperti ramah, sabar, gembira, kerjasama, toleran, tidak egois dan memiliki rasa simpatik. Sebaliknya jika seseorang dibesarkan dalam keluarga yang kurang bahagia, sukar di harapkan orang tersebut menumbuhkan kepribadian yang positif.

Kondisi ayah yang menjaga jarak pada kehidupan sehari-hari menjadikan ayah tidak bisa dekat secara batiniah maupun mental pada kehidupan anak-anak yang di tinggalkan oleh ibunya.Dalam kesehariannya perilaku anak buruh migran yang jarang ingin masuk sekolah, mengaji, dan tidakmendengarkan perintah neneknya, dan pada kondisinya anak menolak apa yang diperintahkan nenek terutama dalam kegiatan bersekolah, anak merasa malas pergi ke sekolah, bahkan neneknya sampai tidak mau memperingati sang anak lagi karena terlalu lelah, mengingat kondisi sang nenek yang udah tua.

Tetapi perilakunya terbalik jika anak di perhatikan oleh Ayahnya, anak menuruti perintah dari Ayah, dan mudah menerima pertintah dari ayah dengan cara Ayah memberikan sentuhan langsung seperti anak di mandikannya untuk pergi ke sekolah, dipasangkan baju, di berikan uang saku,berdasarkan penelitian yang di lakukan peran seorang Ayah dalam kehidupan anak sulit digantikan oleh orang lain.Tetapi hal semacam itu jarang Ayah melakukan dan menerapkannya kepada anak. Dalam perilaku anak dalam kehidupan sehari-hari, anak sering bermain bersama teman-temannya, bahkan setiap hari waktunya di habiskan untuk bermain bersama teman-temannya, tetapi di dalam kegiatannya, anak sangat nakal, dan sering mengganggu teman-temannya, tetapi dalam hal ini anak lebih mudah emosi di bandingkan dengan teman-temannya yang lain.

\section{Kesimpulan}

Komunikasi yang baik dengan keluarga adalah hal yang sangat diidamkan oleh banyak orang, dalam sebuah keluarga dimana kondisi anak buruh migran memang menjadi suatu permasalahan yang ada di Desa Pandan Wangi, terutama dari pengasuhan, kontrol yang diberikan kepada anak masih kurang terutama dalam kedekatannya dengan anak.Pola komunikasi yang baik adalah pola komunikasi orangtua yang memprioritaskan 
kepentingan anak, dan interaksi yang terjalin tidak hanya dari orangtua ke anak, juga antara orangtua dan anak dengan anak, orangtua harus bisa mengendalikan anak-anaknya. Komunikasi secara terbuka merupakan proses yang menghubungkan antara anggota keluarga yang satu dengan yang lainnnya. Komunikasi dikatakan berhasil jika komunikasi tersebut tidak sebatas dalam penyampaian pesan tetapi harus bersifat terbuka antara yang satu dengan yang lainnya. Komunikasi terbuka bisa menghapus prasangka buruk ataupun kecurigaan yang dapat terjadi dan dapat membangun rasa saling pengetian antara anggota keluarga yang satu dengan yang lainnya, sehingga pesan dapat dipahami di pikirkan akhirnya dapat dilaksanakan.

Narasumber 1 (MYS) keluarga buruh migran yang ditinggalkan ibu dan ayah dan tinggal bersama paman dan bibiknya, dengan keadaan ekonomi keluarga yang cukup baik maka keluarga tersebut terjadi sikap saling pengertian dimana bibik mengambil peran untuk selalu bersikap aktif dalam keluarga karena mengetahui sisi lain dari anak yang diasuhnya, dengan selalu bisa saling memahami dengan suami, sehingga kehadiran anak tidak dipermasalahkan dalam keluarga dan tidak dijadikan sebagai ancaman oleh anggota keluarga yang lain, oleh sebab itu bibik memiliki kepercayaan dan keahlian untuk menyelesaikan tanggung jawabnya dengan memahami pikiran dan perasaan suami dan anak-anaknya, sedangkan si Paman hanya fokus kepada pekerjaan dan bisnis tembakau untuk memenuhi kebutuhan keluarga, dan dalam keluarga tersebut menerapkanpola komunikasi seimbang terpisah (Balance Split Pattern) dimana kesetaraan hubungan tetap terjaga namun dalam pola ini tiap orang memiliki daerah kekuasaan yang berbeda seperti bibik di percaya dalam mengurus anak dan paman di percaya untuk urusan bisnis tembakaunya, Perilaku komunikasi anak yang diterapkan keluarga yang ditinggalkan oleh kedua orangtuanya memiliki perilaku komunikasi empati yang cukup baik karena anak mampu bekerjasama dengan anggota keluarga yang lain dalam proses interaksi kehidapan yang dijalankan sehari-harinya.

Narasumber 2 (RRA) keluarga buruh migran yang ditinggalkan oleh Ayahnya keluar negeri dan di asuh oleh Ibunyamemiliki hubungan yang kurang baik karena ibu tidak terbuka dalam berkomunikasi dengan suami, begitupun sebaliknya, suami jarang berkomunikasi dengan isteri dalam membicarakan persoalan anaknya, karena dipengaruhi oleh hubungan yang tidak harmonis, jadi dalam hal ini terjadi komunikasi yang tidak 
sejalan antara ibu dan ayah, sesuatu yang dilarang oleh ibunya seolah-olah ayah membiarkan dan mendukung anak dengan cara memenuhi keinginan anak padahal keinginan tersebut belum tentu baik dan dibutuhkan oleh anak, hal ini yang membuat penolakan-penolakan terhadap ibu sering terjadi dan membuat hubungan anak dan ibu kurang baik karena dipengaruhi oleh ayah yang sudah tidak memiliki sosok sentral atau pengarah di dalam keluarga. Dalam komunikasi yang diterapkan menggunakan pola komunikasi yang mengarah kepada komunikasi tak seimbang terpisah (Unbalanced Split Pattern) yaituhubungan terpisah yang tidak seimbang, di mana satu orang dalam keluarga si suami mendominasi. Maka dari itu, satu orang ini secara teratur mengendalikan hubungan dan hampir tidak pernah meminta pendapat kepada isteri. Sedangkan si isteri yang dikendalikan membiarkannya untuk memenangkan argumentasi ataupun membuat keputusan dengan sendiri. Perilaku komunikasi yang diterapkan anak dalam keluarga ini menerapkan perilaku komunikasi menolak karena sering terjadi penolakan apabila ibu melakukan komunikasi dengannya.

Narasumber 3 (MFBP) keluarga buruh migran yang ditinggalkan oleh ibu dan diasuh oleh Ayahnya, dalam kondisi anak yang mempunyai ibu tiri membuat anak terpaksa di asuh oleh neneknya, karena anak jarang diperhatikan dan di kontrol. Ketidaksetaraan hubungan tentu sangat jelas terjadi karena anak diperlakukan berbeda dengan saudara-saudaranya yang lain, saudara satu ayah yang didapatkan melalui ibu tirinya, saudara-saudaranya yang lain tinggal bersama ayah dan ibu sementara anak tinggal berdua dengan dengan neneknya, sementara Ayah jarang memperhatikan kondisi anak, dalam hal inianak selalu menolak apa yang sering diperintahkan neneknya. Akan tetapi anak akan memberikan respon yang baik apabila ayah memperhatikan dan memberikan sentuhan tangannya kepada anak akan cepat menerima apa yang diperintahkan oleh ayah, jadi peran ayah dalam keluarga buruh migran yang ditinggalkan oleh ibu tidak bisa diganti oleh siapaun, adapun ayah tidak terbuka dalam penyampaian pesan kepada anak, ayah secara diam-diamdalam memenuhi kebutuhan dan tidak terbuka dalam penyampaian informasi di dalam keluarganya. Memenuhi kebutuhan anak secara diam-diam membuat komunikasi yang diterapkan dalam keluarga tidak terbuka karena tidak diketahui oleh isteri. Dan berdasarkan uraian di atas komunikasi yang terjadi pada keluarga buruh migran yaitu menerapkan pola komunikasi(Unbalanced Split Pattern) 
satu orang dalam keluarga yaitu istri mendominasi karena dilihat dari cara memperlakukan anak tiri dan kadungnya secara berbeda. Maka dari itu, satu orang ini secara teratur mengendalikan hubungan dalam keluarga dan hampir tidak pernah meminta pendapat antara kedua belah pihak yaitu Ibu jarang meminta pendapat kepada anggota keluarga yang lain, sedangkan suami yang dikendalikan membiarkannya untuk memenangkan argumentasi ataupun membuat keputusan dengan membiarkan anak di asuh oleh neneknya.Perilaku komunikasi anak sering menolak apa yang diperintahkan oleh nenek, karena peran ayah dalam keluarga buruh migran tidak bisa digantikan oleh siapapun. Jadi perilaku komunikasi yang terjadi pada anak tergantung dari bagaimana orangtua mengasuh, membimbing anak, membimbing pendidikan dalam keluarga.

\section{Saran}

Saran dari penelitian ini yaitu :

1. Orangtua harus bisa memperlakukan anak-anaknya secara adil, supaya kesetaraan hubungan antara ayah, ibu dan anak-anak tetap terjaga supaya anak merasa diperhatikan dari segi kehidupannya sehingga komunikasi dapat berjalan dengan baik.

2. Orangtua harus bisa menerapkan komunikasi secara terbuka dalam keluarga supaya tidak terjadi kesalahpahaman antara anggota keluarga yang lain dan memberikan dampak pada perkembangan anak.

4. Suami dan Istri harus bisa bekerjasama dengan baik dalam mengurus anak, supayaanak bisa mempersepsikan segala sesuatu yang diperintahkan kedua orangtuanya selalu bersifat baik.

3. Perlu adanya penelitian lanjutan tentang persoalan-persoalan keluarga buruh migrandalam membangun komunikasi yang baik dengan keluarga.

\section{Referensi}

Abriyoso.2012.Hubungan Efektivitas Komunikasi Antar Pribadi dalam Keluarga dengan Motivasi Belajar Anak di Sekolah.E-Journal, Bandung.

Attayamini Rahmah.2014.Upaya Membangun Komunikasi antar Pribadi yang Efektif antara Siswa dan Guru.UIN Sunan Kalijaga Yogyakarta.

Ambar. 2017.PengantarImuKomunikasi. https://pakarkomunikasi.com/model-modelkomunikasi/amp. Di akses tanggal 4 November 2018

Budyatna Muhammad.2015.Teori-teori Komunikasi antar Pribadi. Jakarta. Prenada Media Group. Hal. 59-111.

Budyatna Muhammad dan Mona Ganiem. 2011. Teori Komunikasi antar Pribadi. Jakarta. Kencana Prenada Media Group. Hal. 15-18

Dinas sosial. Tenaga Kerja dan Transmigrasi Kabupaten Lombok Timur 
Djarmah, Bahri, Syaiful.2004. Pola Komunikasi Orang Tua Dan Anak Dalam Keluarga. Jakarta:PT.Reneka Cipta. Hal. 1

De Vito, Joseph A. 2004. The Interpersonal Communication, Boston: publishers design and production service.

Dr.Suhasimi Arikunto. 1985. Prosedur Penelitian. Jakarta. PT.Bina Aksara.

Dewi, U. Mulyana, Deddy. 2015. Pengalaman Komunikasi Keluarga pada Mantan Buruh Migran Perempuan. Universitas Singaperbangsa Karawang dan Universitas Padjajaran.

Effendy, Onong Uchjana. 1993. Ilmu, Teori \& Filsafat. Bandung PT. Citra Aditya Bakti. Hal. 58

Eisenberg, N \& strayer.1987. Emphaty Is Development Cambridge.Cambrige University Pers

Goleman,Daniel.1997.Kecerdasan Emosional Mengapa El Lebih Penting dari EQ.Jakarta.PT Gramedia Pustaka Utama.

Hart,J.2002.The Importance of Fathersin Children's Asset Development. http://fairfield.osn.edu./parent/parentparthjune20.htm/. Di akses tanggal 29 Oktober 2018.

Inayah, Nurul. 2011. Model Pola Asuh Ayah dalam Keluarga Migran di Kabupaten Banyuwangi. Annual international conference on islamic studies AICIS XII.

Kartono, Kartini. 2008.Patologi Sosial 2 Kenakalan Remaja. Jakarta. PT. Raja Grafindo Persada

Koestner, R \& Franz.1990.The family Origins of Emphatic Concerna 26 Years Longitudinal Study. Journal of personality and social physicology and social.

Lestari,Sri. 2012. Psikologi Keluarga. Prenamedia Group. Hal. 3.

Meleong, Lexy. 2003. Metode Penelitian Kualitatif.Bandung. Rosda Karya.

M.Alisuf Sabri. 1996. Psikologi pendidikan. Jakarta. Pedoman Jaya. Hal. 10.

Mufidah Hilmi.2008.Komunikasi antara Orangtua dengan Anak dan Pengaruhnya Terhadap Perilaku Anak.Universitas Islam Negeri Jakarta

Novalia, Seruni. 2015. Perubahan Perilaku Sosial Ekonomi Mantan Tenaga Kerja Wanita (TKW) dalam Keberlangsungan Hidup Keluarga Persfektif Ekonomi Islam. Ekonomi Syariah. IAIN. Purwokwero

Nawawi, Hadari.1992. Instrumen Penelitian Bidang Sosial. Yogyakarta. Gajah Mada University Press. Hal. 209.

P.Sondang Siagian.1985. Organisasi Kepemimpinan dan Perilaku Administrasi. Jakarta Gunung agung. Hal. 54-57.

Permatasari, Beti. 2015. Dampak Psikologi Anak yang Ditinggalkan Orangtuanya Merantau.Universitas Muhammadiyah Surakarta. Hal.57

Rooney Kountur. 2004. Metode Penelitian:Untuk Penulisan skripsi dan Tesis. Jakarta. Ppm

Saputra,Hadi.2014. Pola Komunikasi dalam Keluarga.Lubmazal

Suciati.2015.Komunikasi Interpersonal. Litera.Yogyakarta. Hal. 143.

Setyawan, DA.2012.Konsep Dasar Keluarga.Mk.Asuhan Kebidanan Komunitas.

Wiryanto. 2004. Pengantar Ilmu Komununikasi Grasindo. Jakarta. Hal. 6.

Yedi Kurniawan. 1992.Pendidikan Anak Sejak Dini Hingga Masa Depan Tinjauan Islam dan Permasalahannya. Jakarta. CV Firdaus. Hal. 18. 